INEEL/EXT-2000-01455

October 2000

\title{
Oxidation and Volatilization from Tantalum Alloy T-222 During Air Exposure
}

\author{
G. R. Smolik \\ D. A. Petti \\ J. P. Sharpe \\ S. T. Schuetz
}




\title{
OXIDATION AND VOLATILIZATION FROM TANTALUM ALLOY T-222 DURING AIR EXPOSURE
}

\author{
Galen R. Smolik \\ David A. Petti \\ J. P. Sharpe \\ Stan T. Schuetz
}

Published October 2000

\begin{abstract}
Idaho National Engineering and Environmental Laboratory Idaho Falls, Idaho 83415
\end{abstract}

Prepared for the U.S. Department of Energy Office of Energy Research Under the DOE Idaho Operations Contract DE-AC07-99ID13727 


\begin{abstract}
Tantalum alloys are one of the refractory metals with renewed consideration for high temperatures in fusion reactor applications. Tantalum alloys perform well in protective environments but oxidized readily in gases containing higher oxygen levels. In addition, the radioactive isotope Ta-182 would be produced in tantalum and could be a significant contributor to dose if mobilized. Other isotopes of importance are produced from tungsten and hafnium. Mobilization of activated products during an accident with air ingress is therefore a safety issue. In this study, we measured the extent of oxidation and mobilization from tantalum alloy T-222 oxidized in flowing air between 500 and $1200^{\circ} \mathrm{C}$. This alloy nominally contains $10 \mathrm{wt} \%$ tungsten, $2.5 \mathrm{wt} \%$ hafnium and $0.01 \mathrm{wt} \%$ carbon. We found that the mobilization of $\mathrm{Ta}$ and $\mathrm{Hf}$ was closely linked to the occurrence of oxide spalling. These elements showed no migration from the test chamber. Some $\mathrm{W}$ was mobilized by volatilization as evidenced by transport from the chamber. Tungsten volatilization could occur primarily during initial stages of oxidation before an oxide scale forms and impedes the process. The mobilization of $\mathrm{Ta}$ and $\mathrm{W}$ are presented in terms of the mass flux $\left(\mathrm{g} / \mathrm{m}^{2}-\mathrm{h}\right)$ as a function of test temperature. These measurements along with specific designs, activation calculations, and accident scenarios provide information useful for dose calculations of future fusion devices.
\end{abstract}




\section{SUMMARY}

In this report we present the results of experimental measurements of the oxidation and mobilization of tantalum, tungsten and hafnium from the tantalum alloy T-222. Specimens of the alloy were exposed to flowing air between 500 and $1200^{\circ} \mathrm{C}$. After exposure the extent of oxidation and the character of the oxide were determined by mass change, optical and electron microscopy, x-ray diffraction, and particle size analysis. The mobilization of the three elements mentioned above were determined by chemically removing the oxides from the test components, dissolving the oxides, and analyzing the solutions with inductively coupled plasma-atomic emission spectroscopy (ICP-AES).

The experimental results are presented in Section 3. Photographs of the specimens in Section 3.1 provide good indications of the amount of oxide spalled and powder formed at the various test conditions. The amounts and rates of oxidation as determined from mass change and alloy recession are discussed in Section 3.2 (and reported in Table 1). Illustrations of the oxide scales formed at the various temperatures as revealed by SEM are presented in Section 3.3. Powder was formed most abundantly at $700^{\circ} \mathrm{C}$. We performed particles size analysis by various methods and have reported the results in Section 3.4. Metallographic cross sections were used to show the features and thicknesses of oxide scales and internal effects from oxidation in Section 3.5. Internal effects included dissolved oxygen that increased hardness and made the alloy brittle. Phase determinations from x-ray diffraction are reported in Section 3.6. Mass flux determinations $\left(\mathrm{g} / \mathrm{m}^{2}-\mathrm{h}\right)$ for tantalum, tungsten and hafnium at the various temperatures are presented in Section 3.7.

Experimental results are discussed in Section 4. We conclude that the mobilization of tantalum and hafnium is linked to the oxide spalling process because the oxides of these elements have very low volatility. Tungsten on the other hand has very volatile $\mathrm{WO}_{3}$ polymeric species. We found that some tungsten was mobilized by volatilization. This was evident by increased mobilization with temperature and transport out of the reaction chamber. The mobilization of tantalum actually decreased with temperature which correlated with less particulate formation. We found little evidence of tantalum transport beyond the test chamber. This indicates that the oxide powder that spalled from the specimens has a bw susceptibility to being transported. Upon comparing mobilization rates with a previously tested powder metallurgy (PM) alloy, containing $95 \mathrm{wt} \%$ tungsten and $0.1 \mathrm{wt} \%$ tantalum, we find that the mobilization of tungsten from the T-222 is actually less than that predicted based upon alloy content. This suggests that an oxide scale forms and impedes tungsten loss by volatilization. Mobilization rates of tantalum from the PM product, however, were higher than those from the T222. This exemplifies the influence of oxide spalling and the importance of considering thermal cycling and other factors on the mobilization from tantalum alloys during accidents involving potential oxidation. Oxygen dissolution, embrittlement and impact upon mechanical properties are other issues to consider during off-normal conditions involving the oxidization of tantalum alloys. 


\section{ACKNOWLEDGMENTS}

This work is supported by the U.S. Department of Energy, Office of Science, under the DOE Idaho Operations Contract DE-AC07-99ID13727. The authors wish to thank the following people for their support; Byron White for chemical analyses, Todd Morris for metallographic support, Mike Hankins for SEM, and Arnold Erickson for XRD analyses. 


\section{CONTENTS}

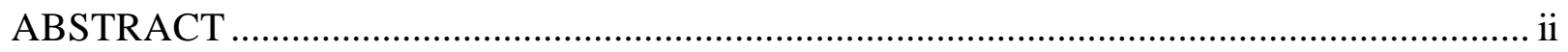

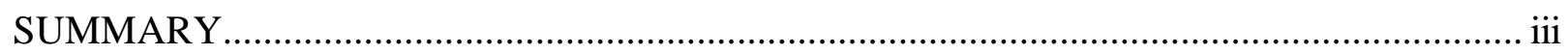

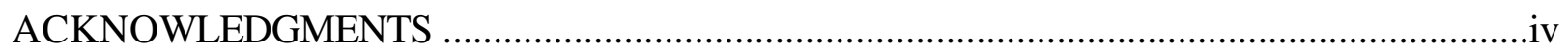

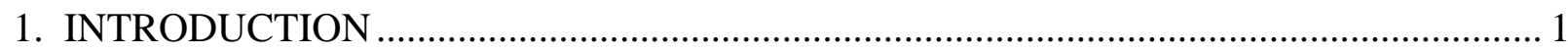

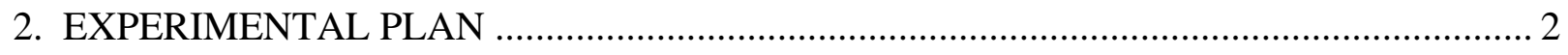

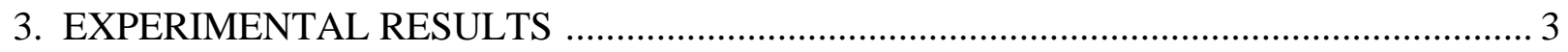

3.1 Visually Apparent Features of Oxidized Specimens ......................................... 3

3.2 Measurements of the Extent of Oxidation.......................................................... 3

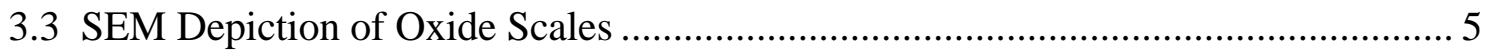

3.4 Particle Size Analysis of Oxide Powder ........................................................... 7

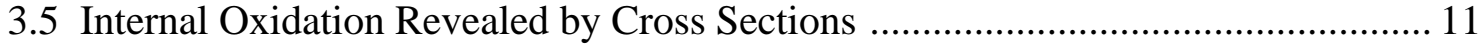

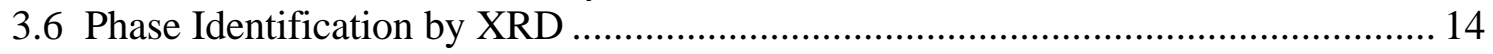

3.7 Mobilization Rates Obtained from ICP-AES Measurements ................................ 14

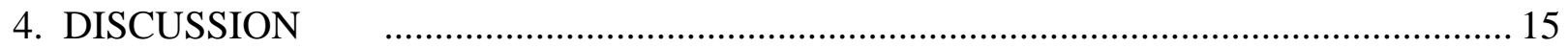

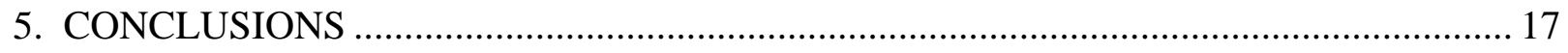

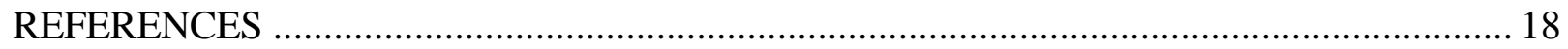

Appendix A: ICP-AES Analyses and Mass Flux Calculations for Elements Mobilized from Tantalum Alloy T-222 .................................... A-1 


\section{INTRODUCTION}

Extensive effort was directed during the mid-1960's to develop tantalum alloys for use for space nuclear reactor systems.[1] Minor oxygen contamination in the alloys promoted corrosion in liquid lithium. Improvements were achieved by alloying small concentrations of hafnium to combine with the oxygen. Alloy T-222 represents one of these improved alloys. Tungsten and a small amount of carbon were added to improve high temperature creep strength. Such alloys have received renewed interest within the fusion community for use in liquid metal coolant systems. Potential mobilization of activated products during operation or accidents with ar ingress is a safety concern. Tantalum alloys readily dissolve oxygen and oxidize above $500^{\circ} \mathrm{C}$. Oxidation kinetics are complexly influenced by oxygen levels, oxygen dissolution, and the nucleation and growth of substoichiometric oxides of various oxidation states.[2,3,4] The solubility of oxygen in tantalum ranges from 2 to 4 atomic percent between 800 and $1200^{\circ} \mathrm{C}$. After dissolving sufficient oxygen into the matrix heterogeneous nucleation of rod or plate-like metallic suboxides referred to as $\mathrm{TaO}_{\mathrm{x}}, \mathrm{TaO}_{\mathrm{y}}$, and $\mathrm{TaO}_{\mathrm{z}}$ can occur. An oxide scale of $\beta$-phase $\mathrm{Ta}_{2} \mathrm{O}_{5}$ ultimately forms at high temperatures and oxygen levels. Oxidation kinetics progressively change from logarithmic, to parabolic, to linear modes with higher temperatures and oxygen pressures and longer times.[2,3] We would expect linear oxidation kinetics to readily occur at $600^{\circ} \mathrm{C}$ in air based upon the report by Kofstad.[2] Tantalum oxides have low vapor pressures. Volatilization has been reported to occur at low pressures, e.g., $10^{-5}$ torr $\mathrm{O}_{2}$ and high temperatures $\left(1600\right.$ to $\left.1700^{\circ} \mathrm{C}\right)$. Vaporizing species at these conditions are $\mathrm{TaO}$ and $\mathrm{TaO}_{2}$.[2] Hafnium oxide is also very stable with negligible vapor pressure. Tungsten forms various volatile $\mathrm{WO}_{3}$ polymeric species. We have measured volatilization from tungsten alloys.[5,6] The volatilization of $\mathrm{WO}_{3}$ is enhanced by even small amounts of water vapor. The objectives of this study are to characterize the nature of the oxide scales formed on the T-222 alloy at various temperatures during the air exposures, to quantify mobilization of Ta, W, and Hf, and verify the mechanisms associated with the mobilization of each of these elements. 


\section{EXPERIMENTAL PLAN}

Specimens were prepared from a 0.1-in. thick plate of Alloy T-222. The nominal dimensions of the specimens were $2.54 \mathrm{~cm} \times 2.54 \mathrm{~cm} \times 0.25 \mathrm{~cm}$. They had a mass of about 30 grams and a surface area of about $15 \mathrm{~cm}^{2}$. They were polished to a 600-grit finish and cleaned with ethanol. The specimens were tested in a $4 \mathrm{~cm}$ diameter quartz chamber heated in a $36 \mathrm{~cm}$ long muffle furnace. Air supplied from a cylinder was flowed through a column of Drierite and preheated to $400^{\circ} \mathrm{C}$. The air was vented to the atmosphere at the ambient pressure at the INEEL of about 650 $\mathrm{mm} \mathrm{Hg}$. A flow rate of one liter per minute (STP) was maintained during all tests. This flow rate and the atmospheric pressure at the INEEL pressure produced gas velocities at specimen surfaces ranging from 0.04 to 0.08 meters per second over the temperature range of 500 to $1200^{\circ} \mathrm{C}$. The gas then flowed through a $1.5-\mathrm{cm}$ diameter quartz tube packed with quartz wool. The latter components extended from the furnace reaching near ambient temperatures at the outlet. The specific test temperatures and times are given in Table 1. The test durations were varied to provide longer exposures at lower temperatures. Mass changes of specimens were measured and oxides characterized. The oxidized specimens were examined and photographed. Cross sections of selected specimens were prepared and metallographically examined. Oxidized specimens and oxides were also examined using scanning electron microscopy, x-ray diffraction, and particle size analyses by image analyses and a Coulter particle size analyzer. Particles of oxides transferred to the quartz components were removed and dissolved with solutions of hydrofluoric and nitric acid. These solutions were chemically processed and analyzed by ICP-AES. Distributions of mobilized elements within the test system were thus determined.

Table 1. Test matrix and results from tantalum alloy T-222 tested in air.

\begin{tabular}{|c|c|c|c|c|c|c|c|}
\hline Specimen & $\begin{array}{c}\text { Temperature, } \\
{ }^{\circ} \mathrm{C}\end{array}$ & $\underset{\mathrm{h}}{\mathrm{Time}}$ & $\begin{array}{c}\text { Mass gain, } \\
\mathrm{g}\end{array}$ & $\begin{array}{c}\text { Rate of oxygen } \\
\text { pickup, } \\
\text { g/h }\end{array}$ & $\begin{array}{c}\text { Oxygen } \\
\text { content, at } \%\end{array}$ & $\begin{array}{l}\text { Alloy loss } \\
\text { per side, } \\
\text { mm }\end{array}$ & $\begin{array}{l}\text { Oxidation } \\
\text { rate, } \\
\mathrm{mm} / \mathrm{h}\end{array}$ \\
\hline & & & & & & & \\
\hline Ta1 & 500 & 81 & 0.0094 & 0.0001 & 0.4 & 0.07 & $9 \mathrm{E}-4$ \\
\hline $\mathrm{Ta} 2$ & 600 & 55 & 1.9134 & 0.0348 & 41.9 & & \\
\hline $\mathrm{Ta} 3$ & 700 & 55 & 0.5502 & 0.0100 & 19.2 & & \\
\hline $\mathrm{Ta} 4$ & 800 & 48 & 3.9742 & 0.0828 & 60.0 & & \\
\hline Ta5 & 900 & 8 & 1.7391 & 0.2174 & 39.6 & 0.27 & $3.4 \mathrm{E}-2$ \\
\hline Ta6 & 1000 & 6 & 3.0939 & 0.5157 & 53.9 & & \\
\hline $\mathrm{Ta} 7$ & 1100 & 4 & 2.1096 & 0.5274 & 44.3 & & \\
\hline $\mathrm{Ta} 8$ & 1200 & 2 & 1.5479 & 0.7740 & 36.9 & 0.27 & $1.4 \mathrm{E}-1$ \\
\hline
\end{tabular}

(a) The nominal mass of the specimens is $30 \mathrm{~g}$. Specimen mass was weighable to 0.0001 gram. Measurements of the metal core of specimens varied by $\pm 0.02 \mathrm{~mm}$ for the $500^{\circ} \mathrm{C}$ test and by $\pm 0.1 \mathrm{~mm}$ for the tests at 900 and $1200^{\circ} \mathrm{C}$. 


\section{EXPERIMENTAL RESULTS}

\subsection{Visually Apparent Features of Oxidized Specimens}

The extent of visually apparent oxidation and oxide spalling from specimens and in the test chambers provided insight into mobilization rates. Photographs of the specimens tested between 500 and $1200^{\circ} \mathrm{C}$ are shown in Figure 1 . The specimen tested at $500^{\circ} \mathrm{C}$ did not appear significantly different than that of the initial untested specimens. It had a very thin dark oxide. Transition to an advanced stage of oxidation is indicated by a voluminous light yellow oxide forming at one edge. The specimen exposed at $600^{\circ} \mathrm{C}$ had developed a complete scale of yellow oxide. The flat sides and edges had spalled off as large pieces. There was also an oxide powder released from beneath the scale. Some particles of this oxide were apparent in the test chamber. The yellow oxide that developed on the specimen at $700^{\circ} \mathrm{C}$ had turned almost completely into powder. Some of this powder was present in the reaction chamber. The specimen tested for 48 hours at $800^{\circ} \mathrm{C}$ had developed about a $2.5-\mathrm{mm}$ thick oxide scale. The sides and edges had spalled off revealing a thin dark gray core. Some fine yellowish powder was released along with larger flat grayish particles from the zone near the oxide to metal interface. Less of the fine yellowish powder was released when the oxide scales spalled from specimens exposed at $900^{\circ} \mathrm{C}$ and $1000^{\circ} \mathrm{C}$. The pieces of scale appeared to be sintered into a harder oxide. Oxide scales remained mostly intact after the shorter exposures of 4 and 2 hours at $1100^{\circ} \mathrm{C}$ and $1200^{\circ} \mathrm{C}$, respectively. The oxide on the flat surfaces of the specimens appeared partially transparent. This suggests that the oxide is likely tantalum pentoxide, $\mathrm{Ta}_{2} \mathrm{O}_{5}$. The $\mathrm{CRC}$ Handbook of Chemistry and Physics shows this oxide as being a colorless crystalline phase.[7] The sample appeared gray on the flat surfaces due to the underlying oxide at the alloy interface. The translucent nature of the oxide suggests that it was somewhat dense and adherent. A more voluminous yellow oxide formed at the cusp-shaped regions of higher oxidation at the corners of the specimens. This oxide was more typical of the oxides formed at lower temperatures. There were only minor amounts of particles evident in the quartz test chambers. A black deposit formed on the front end of the quartz wool during the $1200^{\circ} \mathrm{C}$ test. This was the only test to show such visually apparent deposit downstream from the specimen.

\subsection{Measurements of the Extent of Oxidation}

The amount of oxidation by the various specimens was obtained from mass change and change in the thickness of the metal core obtained from metallography. Oxygen pickup calculated from sample mass change is given in Table 1. These values have been used to calculate average rates of oxygen pickup $(\mathrm{g} / \mathrm{h})$ and the overall final oxygen content $(\mathrm{at} \%)$ of the specimens. The rates of oxygen pickup increase progressively with temperature except for the test at $700^{\circ} \mathrm{C}$. The oxygen pickup of $0.5502 \mathrm{~g}$, or rate of $0.0100 \mathrm{~g} / \mathrm{h}$, at $700^{\circ} \mathrm{C}$ was less than one-third of that measured at $600^{\circ} \mathrm{C}$. It is possible that some of the fine powdery oxide from the $700^{\circ} \mathrm{C}$ test could have been lost during handling. ICP-AES, however, showed that only about $1 \mathrm{mg}$ of tantalum plus tungsten was recovered from the test chamber for that test. We do not believe that up to one gram of oxygen (or about 5 grams of oxide) could have been lost during handling. Rather, the difference between the 600 and $700^{\circ} \mathrm{C}$ test seems to reflect temperature trends of oxidation rates observed for $\mathrm{Ta}$ and $\mathrm{Nb}$ by other studies.[2,3,8] The transformation of metallic suboxide phases to pentoxides has been suggested as a possible reason for this behavior. 


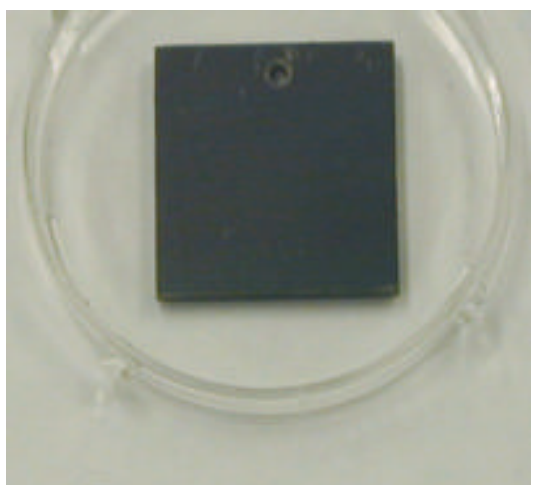

(a) $500^{\circ} \mathrm{C} / 81$ hours

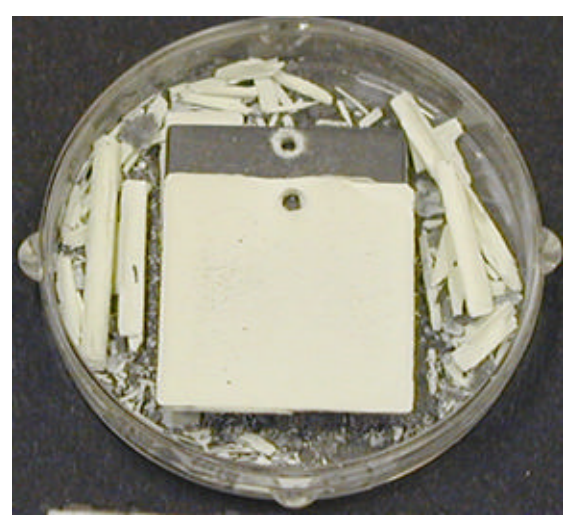

(e) $900^{\circ} \mathrm{C} / 8$ hours

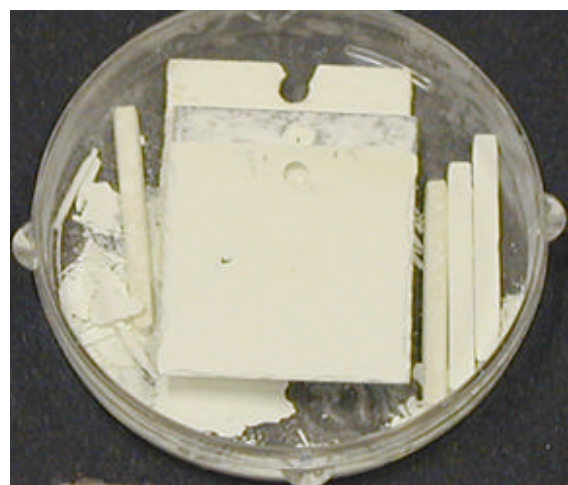

(b) $600^{\circ} \mathrm{C} / 55$ hours

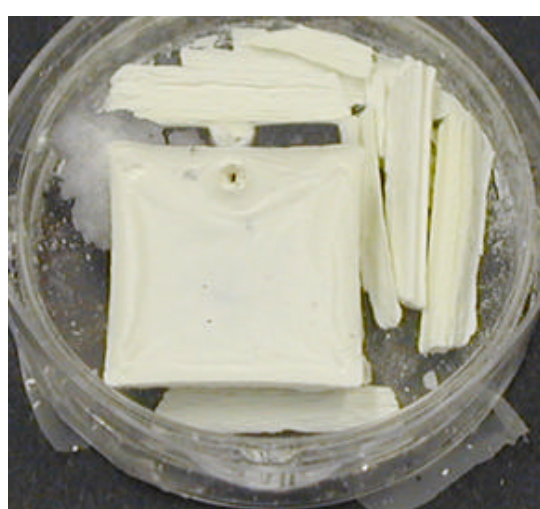

(f) $1000^{\circ} \mathrm{C} / 6$ hours

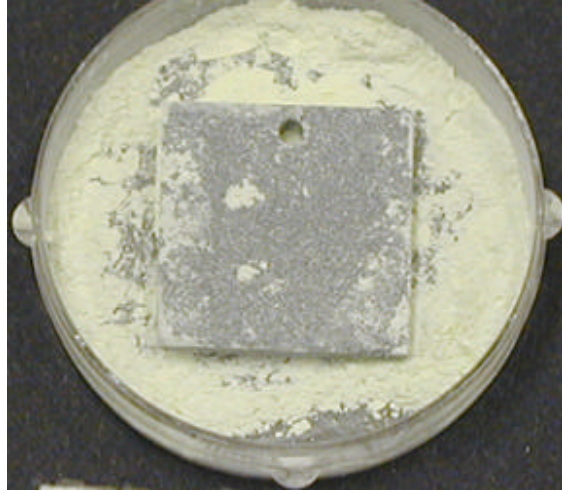

(c) $700^{\circ} \mathrm{C} / 55$ hours

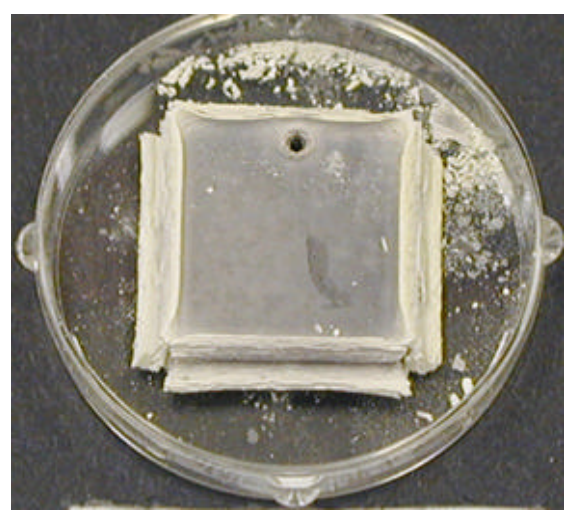

(g) $1100^{\circ} \mathrm{C} / 4$ hours

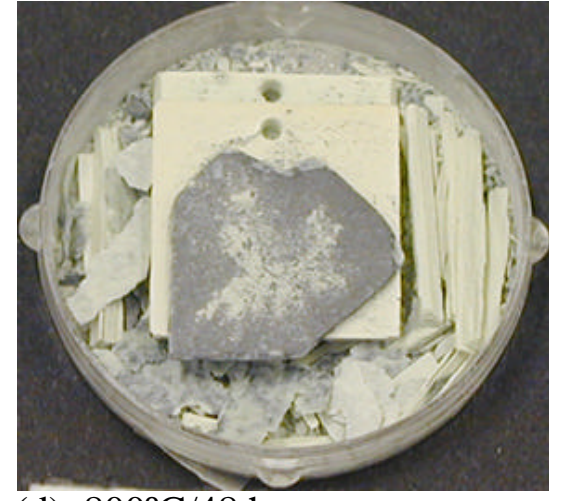

(d) $800^{\circ} \mathrm{C} / 48$ hours

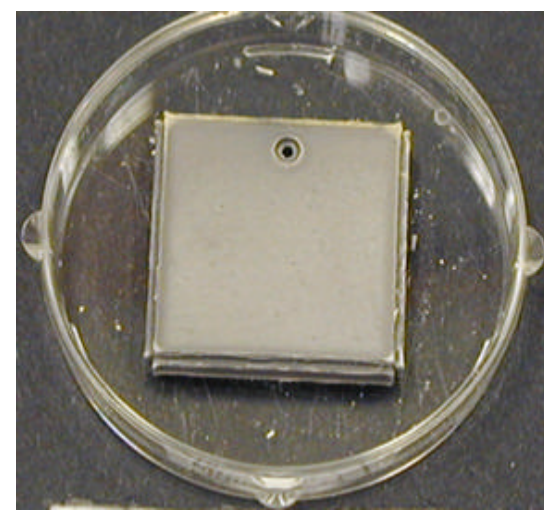

(h) $1200^{\circ} \mathrm{C} / 2$ hours

Figure 1. Appearance of tantalum Alloy T-222 specimens tested in flowing air at various times and temperatures. 
Data in Table 1 show that oxygen in the thin layer from the $500^{\circ} \mathrm{C}$ test contributes less than 0.5 at $\%$ to the specimen. The specimen tested at $800^{\circ} \mathrm{C}$ was the most completely oxidized. It attained an oxygen content of about 60 at $\%$. Since some of the specimen core had still not been reacted, it is likely that much of the oxide had been converted to $\mathrm{Ta}_{2} \mathrm{O}_{5}$, which contains 71 at\% oxygen. Alloy recession rates based on metallographic observations are shown in Table 1 for the specimens tested at 500,900 and $1200^{\circ} \mathrm{C}$.

\subsection{SEM Depiction of Oxide Scales}

SEM displayed the morphologies of oxides formed on the specimens. Figure 2 shows a comparison between surfaces of an untested as-polished specimen and the one tested at $500^{\circ} \mathrm{C}$. The untested specimen in Figure 2(a) shows patterns of elongated smeared material formed during the polishing process. Such smearing is indicative of ductile material. Harder carbide inclusions stand out in relief. The SEM image of the specimen tested at $500^{\circ} \mathrm{C}$ in Figure 2 (b) shows microcracks in the laminated oxides formed along the preexisting polishing marks. SEM showed progressive changes in oxide features with increasing temperature. A thicker more fibrous type of oxide formed at $600^{\circ} \mathrm{C}$ as shown in Figure 3(a). Oxide formed at $900^{\circ} \mathrm{C}$ shown in Figure 3(b) was shaped more like platelets. Some small rounded nuclei were beginning to form on the oxide platelets. Figure 3(c) and Figure 3(d) show the oxides formed at 1100 and $1200^{\circ} \mathrm{C}$, respectively. The oxides are composed of small rounded crystals 0.2 to $1 \mu \mathrm{m}$ in diameter. These small crystals appear to be bonded together. The oxides are relatively free of cracks and voids. These features may provide some impediment to the mobilization of tungsten as we discuss later in the interpretation of ICP measurements.

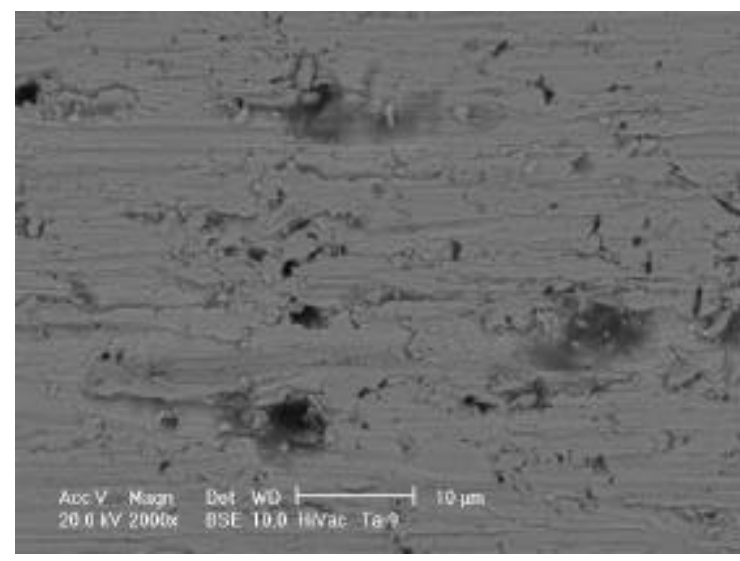

(a) As-polished specimen

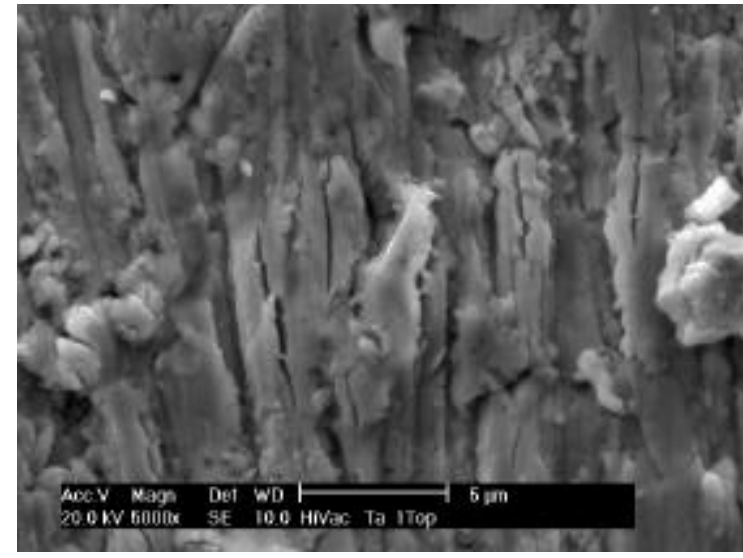

(b) Oxide on $500^{\circ} \mathrm{C}$ specimen

Figure 2. SEM images of the surfaces of T-222 specimens.

The sides of the specimen tested at $900^{\circ} \mathrm{C}$ spalled off as large pieces. The bottom surface of the oxide and the opposing surface from the specimen core are shown in Figure 4. The surfaces are similar. Both surfaces were relatively smooth and had very little texture or fibrous tearing. These are features indicative of a brittle type failure. The material shown may be either the oxide scale or the alloy along the interface that has dissolved a high amount of oxygen. We believe the spalling occurred during cooldown since the features are so sharp and distinct. This appears to be the source of the larger, flat, grayish particles observed in the powders. 


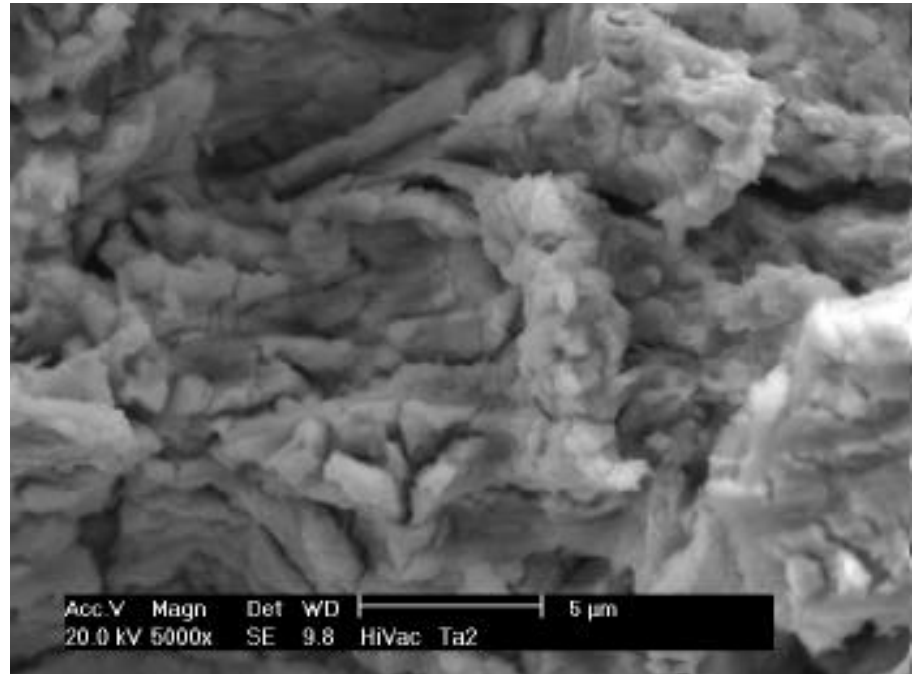

(a) $600^{\circ} \mathrm{C} / 55$ hours

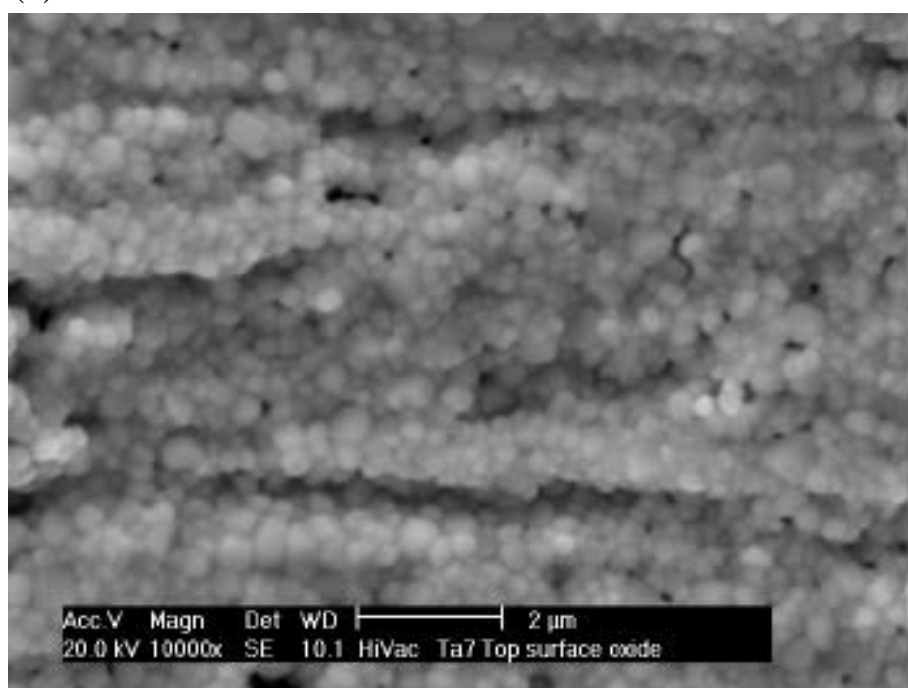

(c) $1100^{\circ} \mathrm{C} / 4$ hours

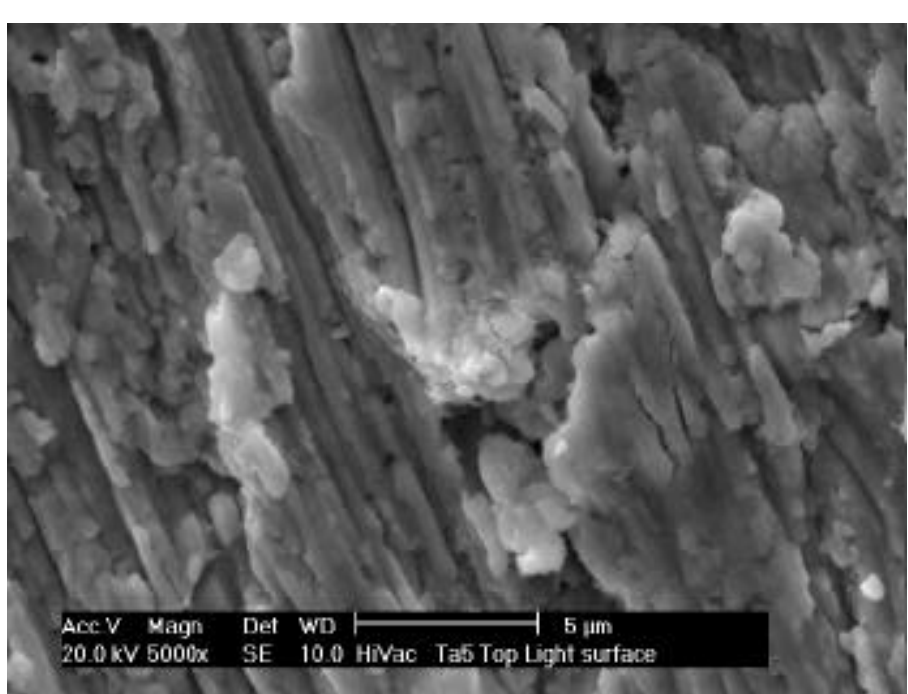

(b) $900^{\circ} \mathrm{C} / 8$ hours

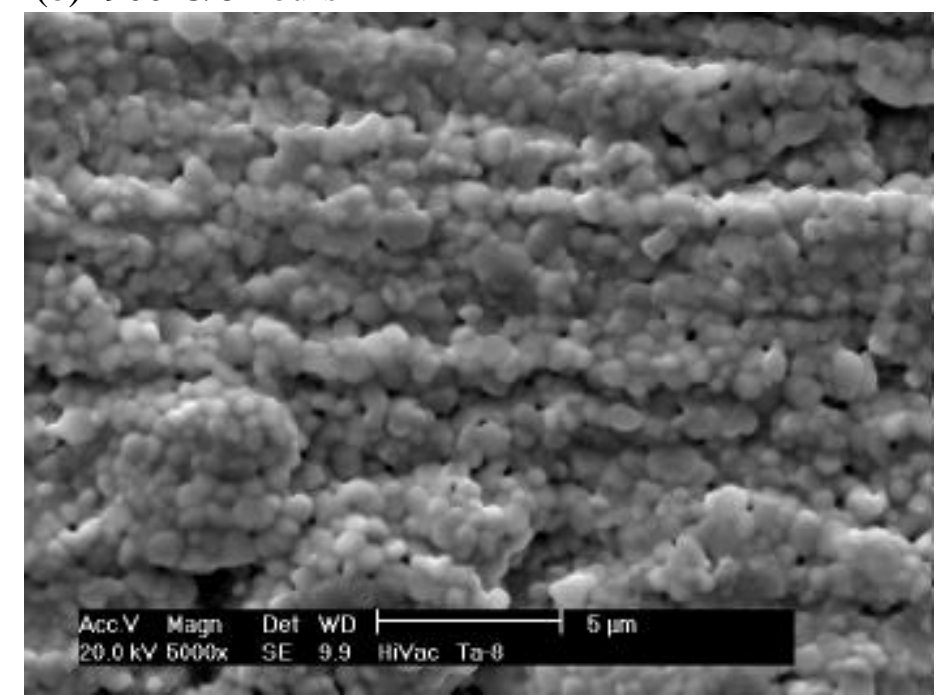

(d) $1200^{\circ} \mathrm{C} / 2$ hours

Figure 3. Outer surfaces of oxides formed on the tantalum T-222 specimens at various temperatures. 


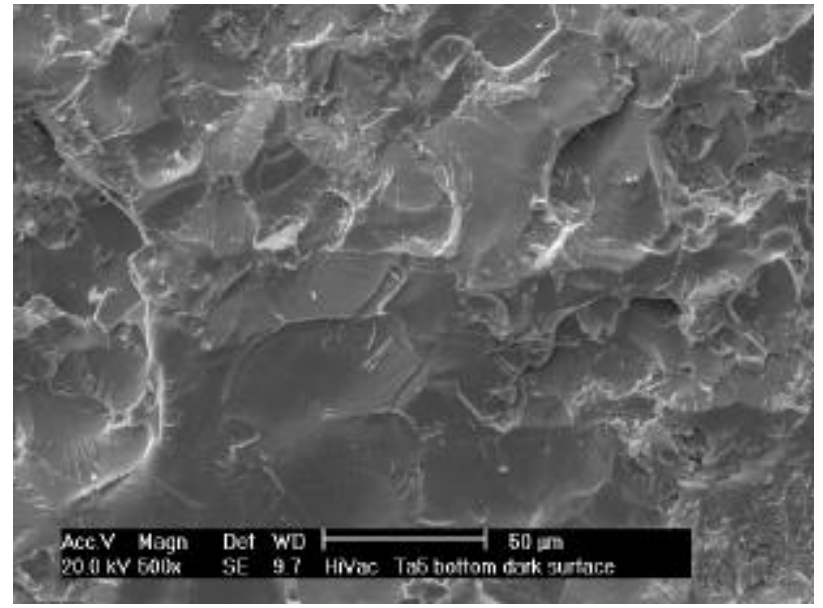

(a)

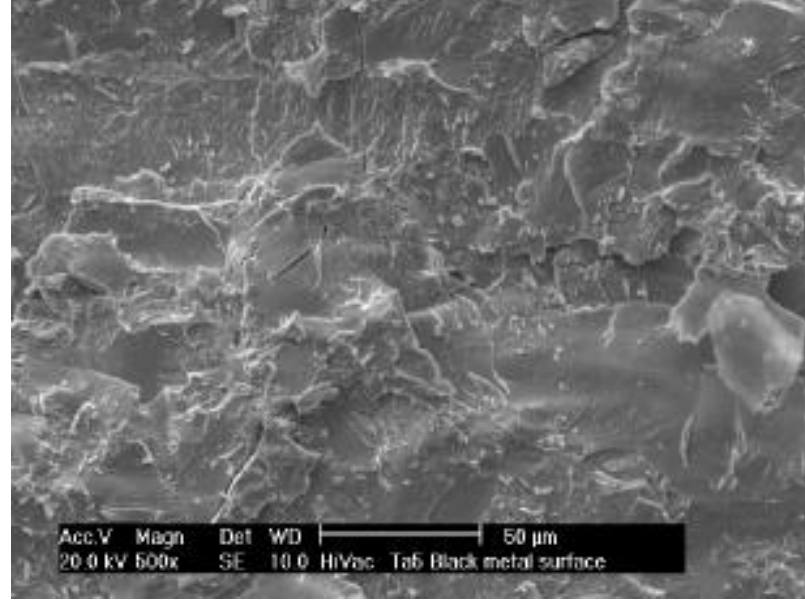

(b)

Figure 4. Surfaces from specimen tested $900^{\circ} \mathrm{C}$ showing brittle type fracture. (a) Bottom surface of spalled oxide. (b) Surface of the remnant specimen core.

\subsection{Particle Size Analysis of Oxide Powder}

We selected the powder from the $700^{\circ} \mathrm{C}$ test to characterize due to the large amount of powder that formed. The SEM images in Figure 5 shows that there are different types of particles. The flat larger particles in Figure 5(a) are the gray particles we believe spalled from near the oxide to metal interface. The smaller irregular shaped particles in Figure 5(b) are those we believe were released from the voluminous outer yellow oxide. The latter type of particles was likely released during the oxidation process at the test temperature. We determined a count-based size distribution using optical microscopy and image analyses. Photographs were obtained from powder dispersed on a slide. Examples of the type of photographs used for the images are shown in Figure 6.

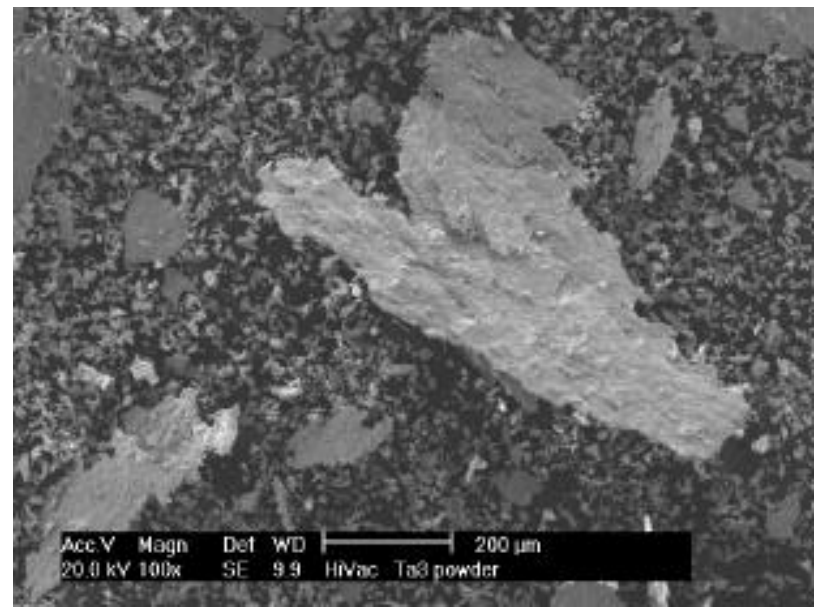

(a)

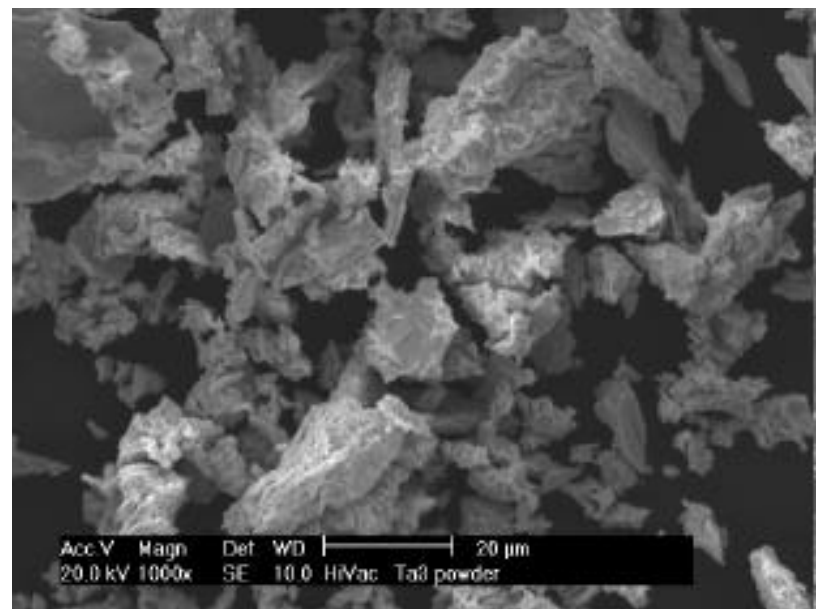

(b)

Figure 5. SEM images of particulate formed from specimen tested at $700^{\circ} \mathrm{C}$. (a) Illustration of various types of particles. (b) Irregular shape revealed for the smaller particles. 


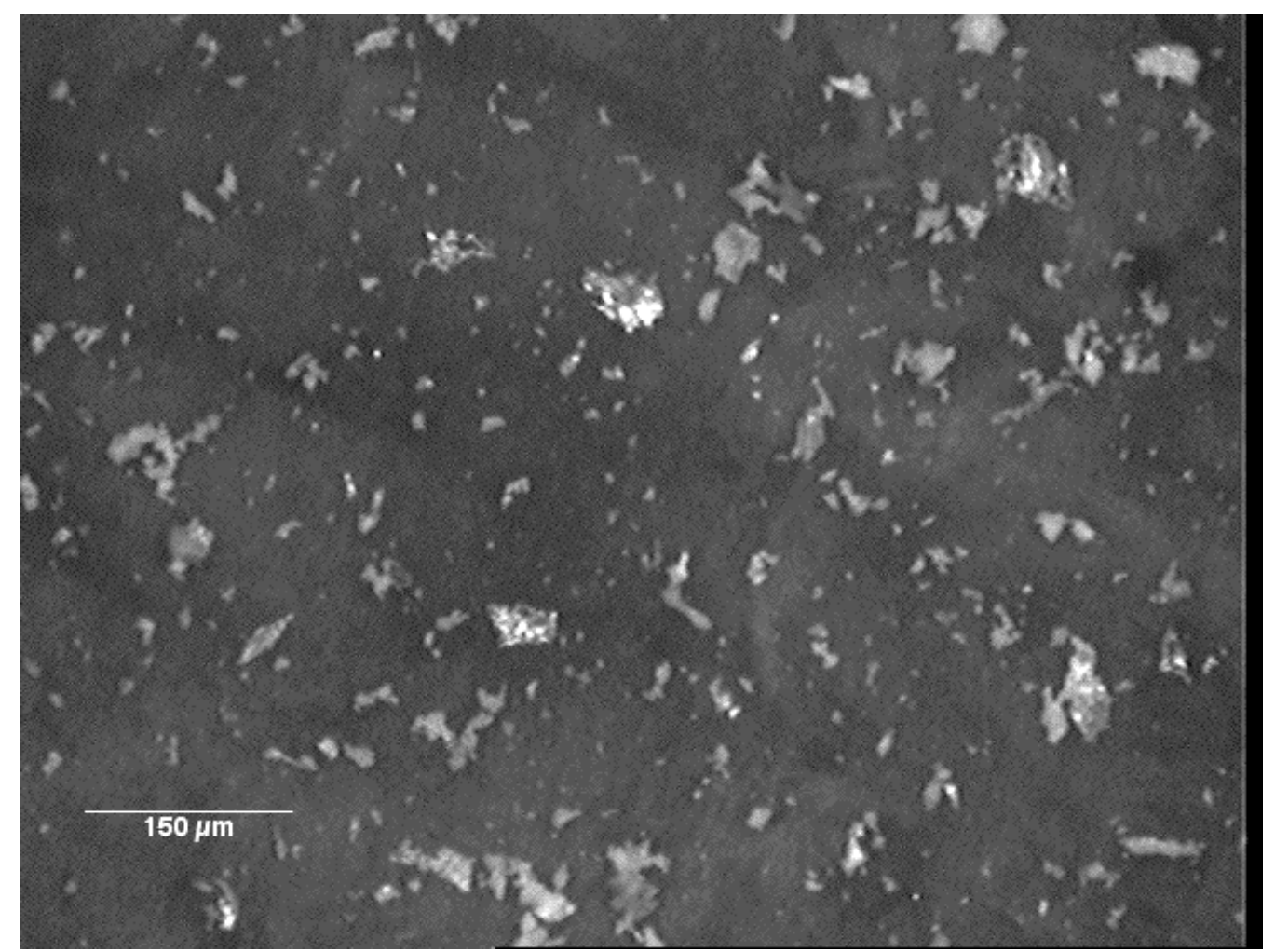

(a)

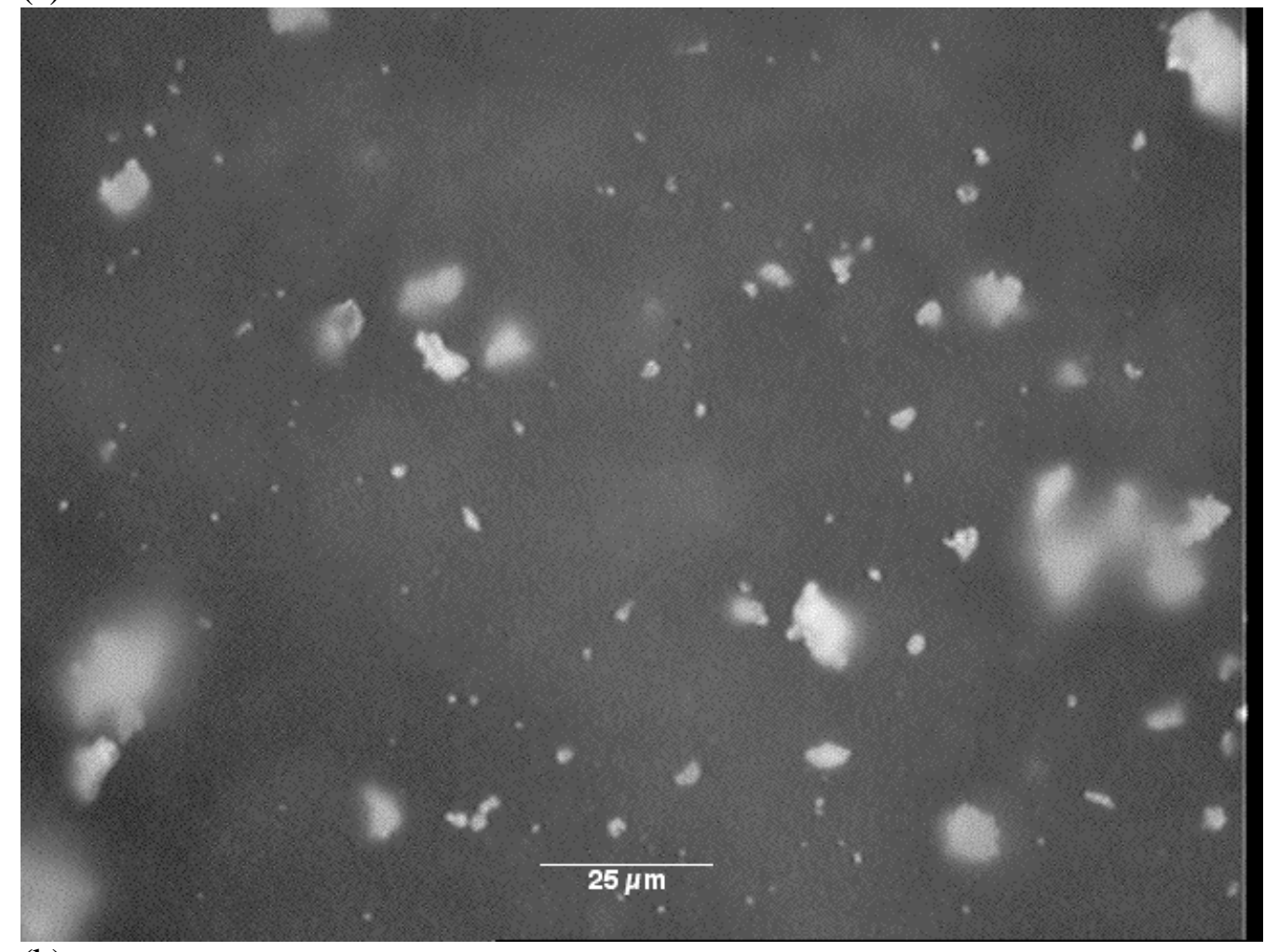

(b)

Figure 6. Examples of photographs used for image analyses. (a) Magnification of 100X. (b) Magnification of 500X. 
Data obtained by counting the particles from the photographs are shown in Figure 7 and Table 2. Deviations from a straight line on the log-probability plot indicate the sampled population is not best described by a lognormal distribution. The data summary in Table 2 shows a geometric median diameter (GMD) of $1.95 \mu \mathrm{m}$ and a geometric standard deviation (GSD) of 2.92. Parameters for a lognormal fit are given in Table 2 and compared with the counted-based data in Figure 8. Particles size distribution based on volume, or mass, were determined with a laser diffraction method with a Counter particle size analyzer. These measurements are compared with the conversion from the count-based fit assuming the Hatch-Choate relationship in Figure 9. The poor correlation shows the influence of the nonspherical, flakelike nature of the particles. The plot of the data in Figure 9 displays shapes characteristic of bimodal distributions. This most likely represents the smaller yellowish particles and the larger flat grayish particles we observed in the powder and as shown by SEM in the Figure 5.

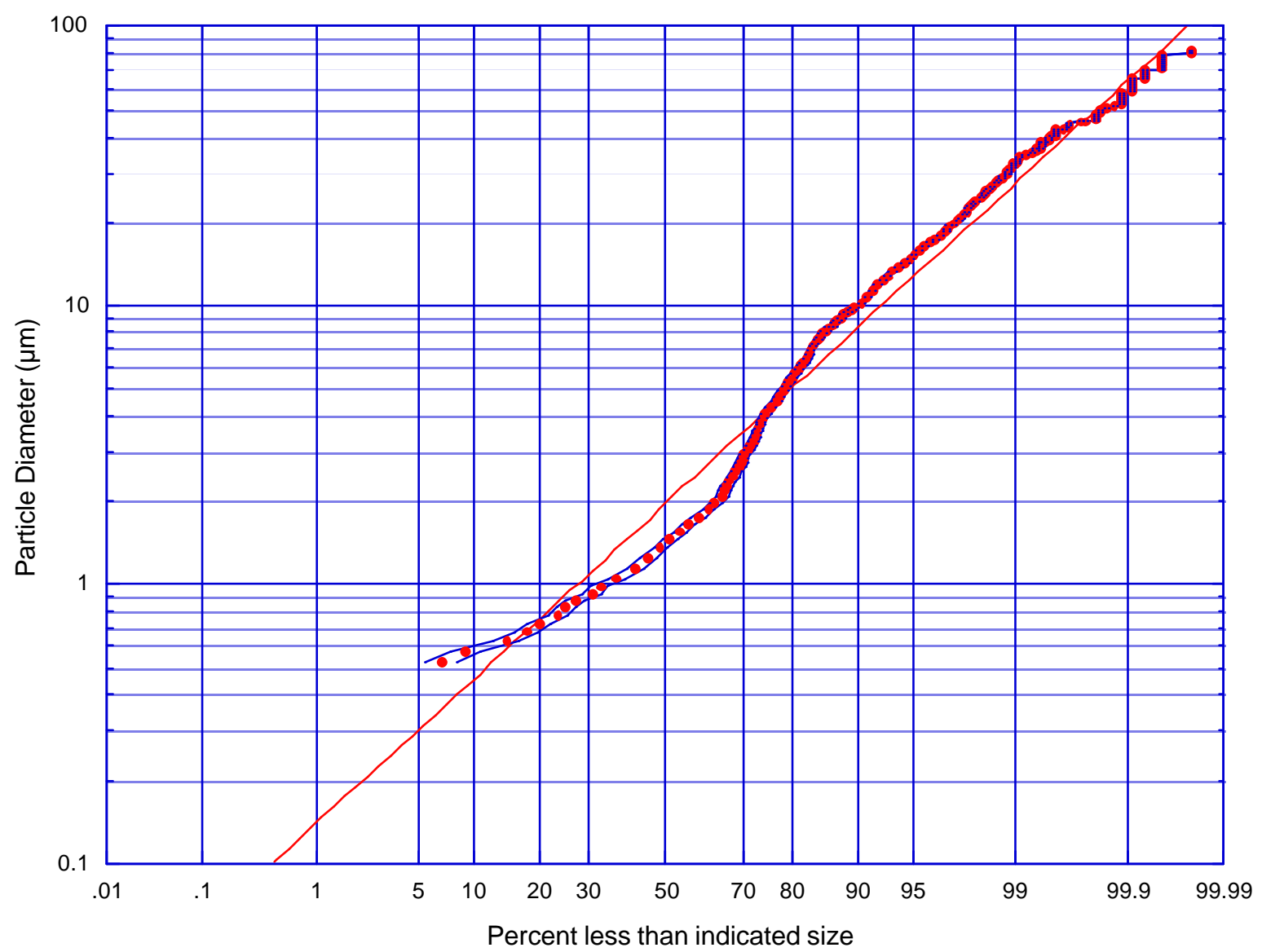

Figure 7. Log-probability plot of partilces from the $700^{\circ} \mathrm{C}$ tests based upon a count-based analysis using optical photographs. 
Table 2. Summary of count based particle size analysis.

\begin{tabular}{|c|c|c|c|c|c|}
\hline $\begin{array}{r}\text { magnifica } \\
\text { number of } \mathrm{i}\end{array}$ & $\begin{array}{l}\text { on, } \\
\text { ages }\end{array}$ & \multicolumn{2}{|c|}{ sampled area ${ }^{1}(\%)$} & counted size range $(\mu \mathrm{m})$ & $\begin{array}{c}\text { total number of particles } \\
\text { (not scaled) }\end{array}$ \\
\hline $100 x$ & 6 & \multicolumn{2}{|r|}{0.224} & $8.00<\mathrm{d}_{\mathrm{p}}$ & 1063 \\
\hline $200 x$ & 6 & \multicolumn{2}{|r|}{0.0558} & $4.50<\mathrm{d}_{\mathrm{p}}<8.00$ & 641 \\
\hline $500 x$ & 6 & \multicolumn{2}{|r|}{0.00893} & $2.10<\mathrm{d}_{\mathrm{p}}<4.50$ & 283 \\
\hline 1000x, & 6 & \multicolumn{2}{|r|}{0.00217} & $0.00<\mathrm{d}_{\mathrm{p}}<2.10$ & 346 \\
\hline \multicolumn{2}{|c|}{ Totals: } & \multicolumn{2}{|r|}{$1.18 \%$} & - & 2,333 \\
\hline \multicolumn{4}{|c|}{ data moments $^{2}$ : } & \multicolumn{2}{|c|}{ log-normal fit moments ${ }^{2}$ : } \\
\hline \multicolumn{3}{|c|}{ GMD $(\mu \mathrm{m}):$} & 1.95 & GMD $(\mu \mathrm{m}):$ & 1.96 \\
\hline \multicolumn{2}{|c|}{ GSD: } & & 2.92 & GSD: & 3.10 \\
\hline \multicolumn{3}{|c|}{ lower $95 \%(\mu \mathrm{m})$ : } & 0.23 & $\mathrm{R}^{2}:$ & 0.98626 \\
\hline \multirow{2}{*}{\multicolumn{3}{|c|}{ upper $95 \%(\mu \mathrm{m})$ : }} & \multirow[t]{2}{*}{16.7} & lower $95 \%(\mu \mathrm{m})$ : & 0.20 \\
\hline & & & & upper $95 \%(\mu \mathrm{m}$ & 18.8 \\
\hline
\end{tabular}

1. $\quad$ based on overall filter area of $1.59 \times 10^{9} \mu \mathrm{m}^{2}$

2. $\mathrm{GMD}=$ geometric median diameter, $\mathrm{GSD}=$ geometric standard deviation, $\mathrm{R}=$ linear correlation coefficient

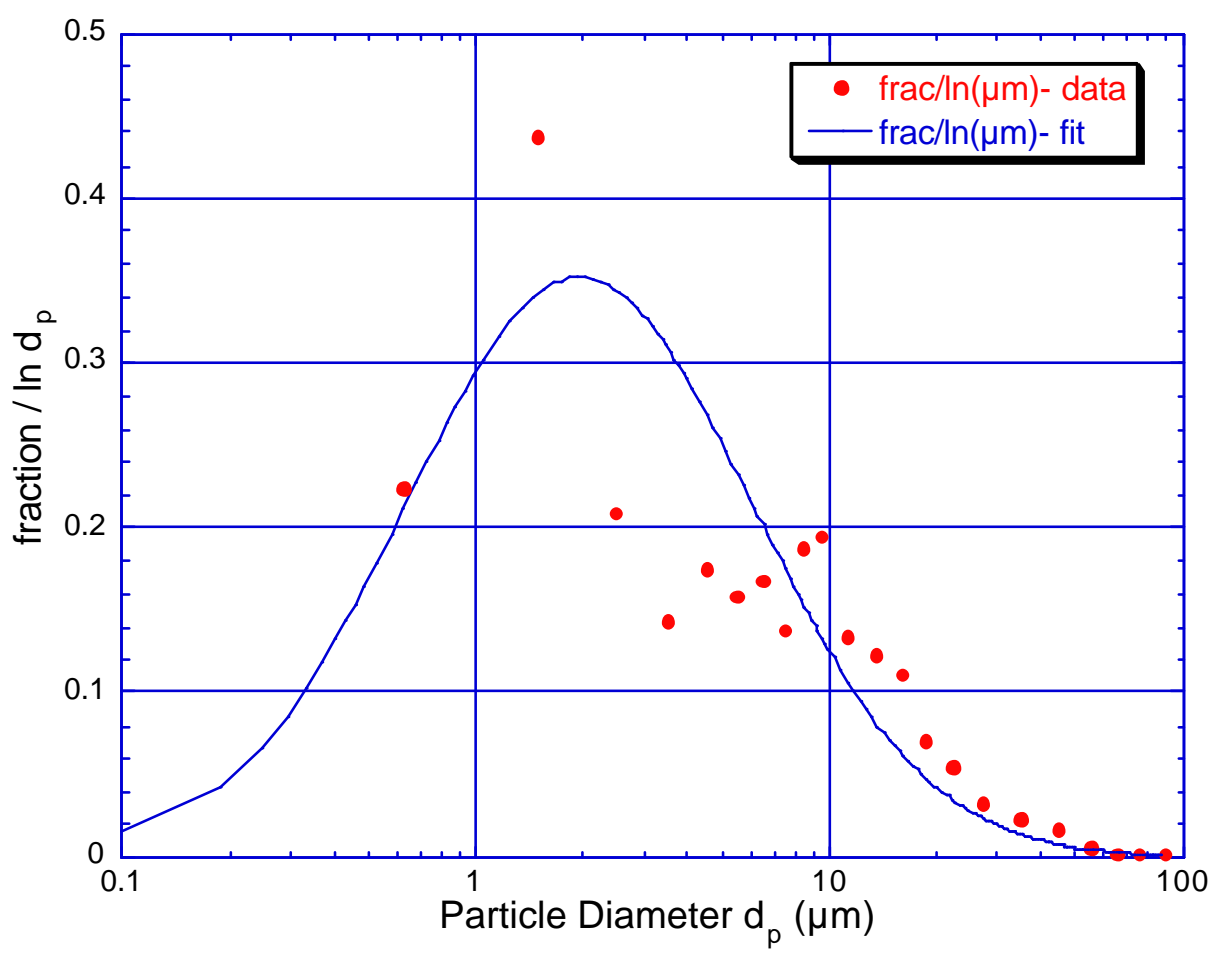

Figure 8. Equivalent count-based particle size distribution determined from data shown in Figure 7 and Table 2. 


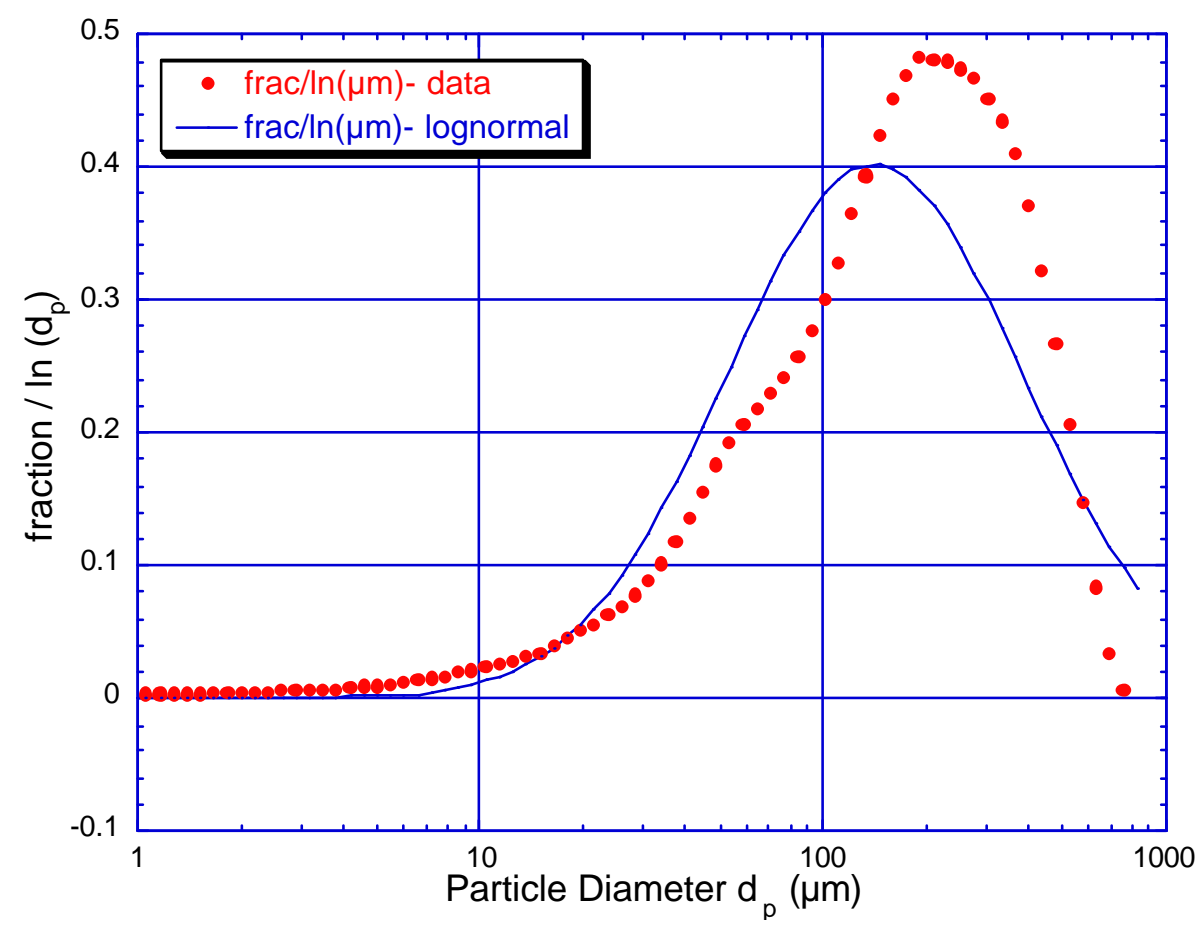

Figure 9. Data from volume- (or mass-) based size distribution for $700^{\circ} \mathrm{C}$ powder compared with a calculated lognormal distribution using Hatch-Choate relationship.

\subsection{Internal Oxidation Revealed by Cross Sections}

Besides revealing oxide scales and oxide to metal interfaces, metallographic cross sections showed evidence of an interstitial gas diffusion into the alloy. An example of the microstructure observed near the surface of the specimen tested at $500^{\circ} \mathrm{C}$ is shown in Figure 10 . The tantalum carbides used for high temperature strength were not apparent in a $0.05-\mathrm{mm}$ thick zone near the surface. Similar zones $0.2 \mathrm{~mm}$ thick were observed in the specimens tested at 900 and $1200^{\circ} \mathrm{C}$. The high adsorption, diffusion and solubility of oxygen, and also nitrogen, into tantalum are well known.[2] The dissolution of these gases would strain and distort the lattice structure. This may enable carbides to be dissolved. It is possible that the precipitates were less apparent due to the polishing process on a hardened surface layer. The carbide inclusions, however, were not apparent with backscattered electrons with the SEM. This indicates that the regions near the surface are more chemically homogeneous than at interior locations where carbides exist. The diffusion of the interstitial atomic species into the alloy was illustrated by microhardness measurements. Diamond pyramid hardness profiles were made using a 50-gram weight. The hardness profiles for the specimens tested at 500, 900 and $1200^{\circ} \mathrm{C}$ are shown in Figure 11. All specimens showed increased hardness due to an apparent inward diffusion of some interstitial, presumably oxygen. The measurements in the zone within $0.05 \mathrm{~mm}$ of the surface void of carbides were significantly higher. The depth of diffusion extended to about $0.2 \mathrm{~mm}$ in the $500^{\circ} \mathrm{C}$ specimen. Microhardness readings then remained constant from there to the center of the specimen. Microhardness continuously decreased from the surface to the center of the specimen for the $900^{\circ} \mathrm{C}$ test. The values at the center approached those of the base material at $500^{\circ} \mathrm{C}$. The 
highest near-surface hardness was observed in the specimen tested at $1200^{\circ} \mathrm{C}$. The hardness then decreased to nearly constant values at a depth of 0.5 to $0.75 \mathrm{~mm}$. This showed that oxygen had not diffused completely to the center of the specimen during the two-hour exposure. The hardness within the core, however, was higher than that of the other two specimens. This suggests some change or restructuring of the carbides during the $1200^{\circ} \mathrm{C}$ exposure.

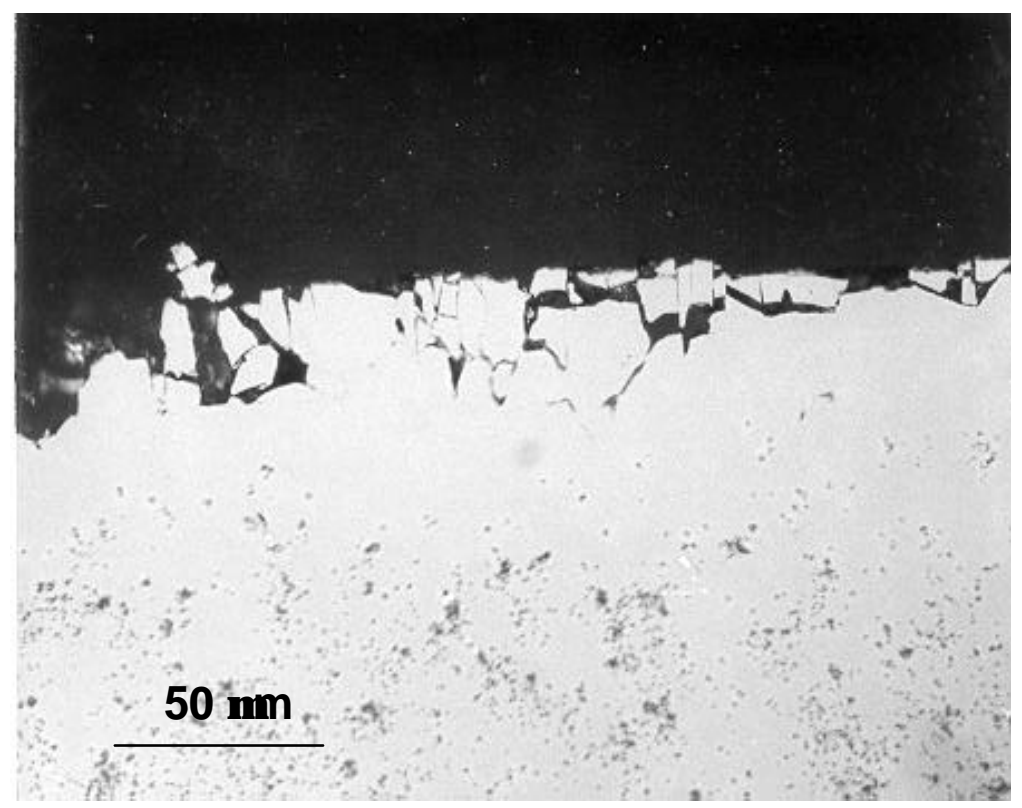

Figure 10. Zone near the surface of the $\mathrm{T}-222$ specimen tested at $500^{\circ} \mathrm{C}$ that does not show the tantalum carbide precipitates.

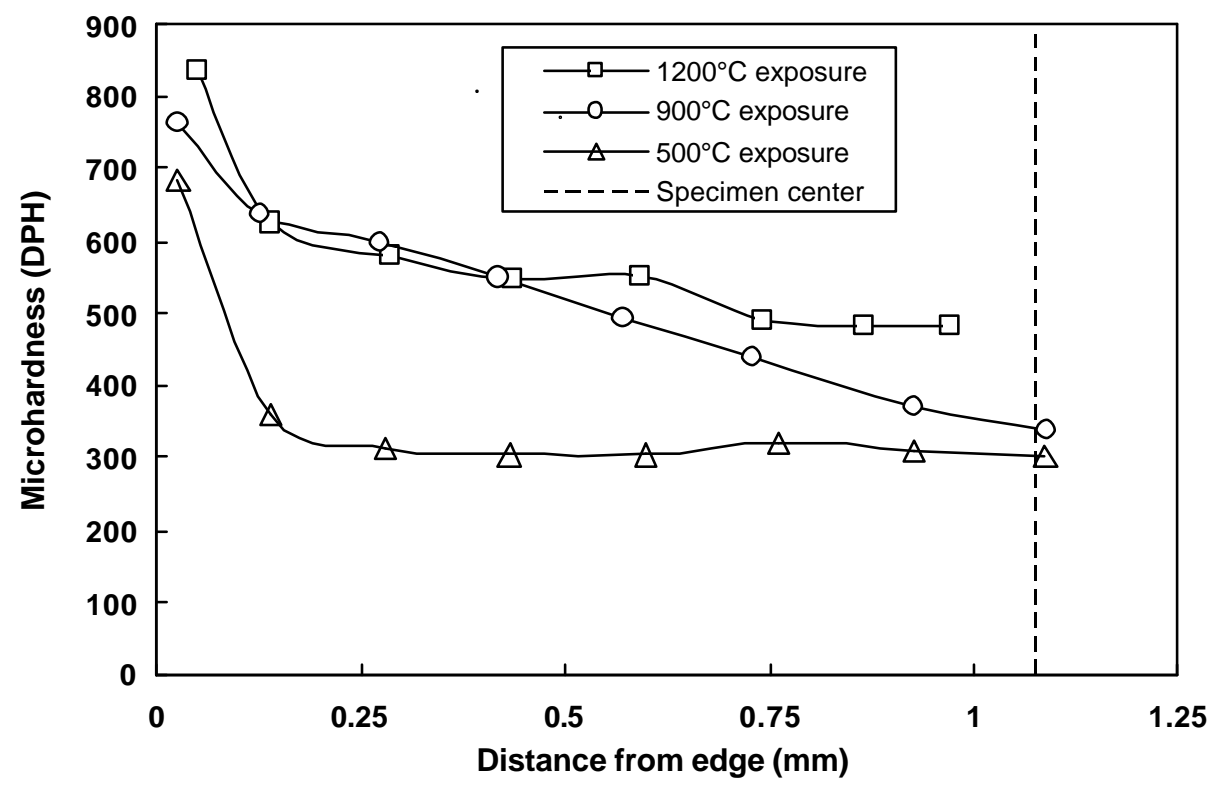

Figure 11. Microhardness profiles of specimens tested at 500,900 and $1200^{\circ} \mathrm{C}$ showing the effect of oxygen diffusion into the specimen. 
A consequence of dissolved oxygen is increased brittleness. Cracks exist within the hardened near-surface zone of the specimen in Figure 10. They are also apparent in the illustrations of the oxide scale and oxide to metal interface of the specimen tested at $1200^{\circ} \mathrm{C}$ in Figure 12 . The cracks in Figure 12(a) extend deep into the metal substrate showing that the metal has become embrittled. The micrograph in Figure 12(a) shows that separation has occurred within the scale. The scale was still intact at other locations as shown in Figure 12(b). Thus the scale did not spall off during cooldown. Figure 12(a) shows some other features of the oxide scale. These are the enhanced oxidation resulting in the cusp shape at the corners, and porosity and cracking in the oxide scale due to the volumetric expansion from the oxide formation.

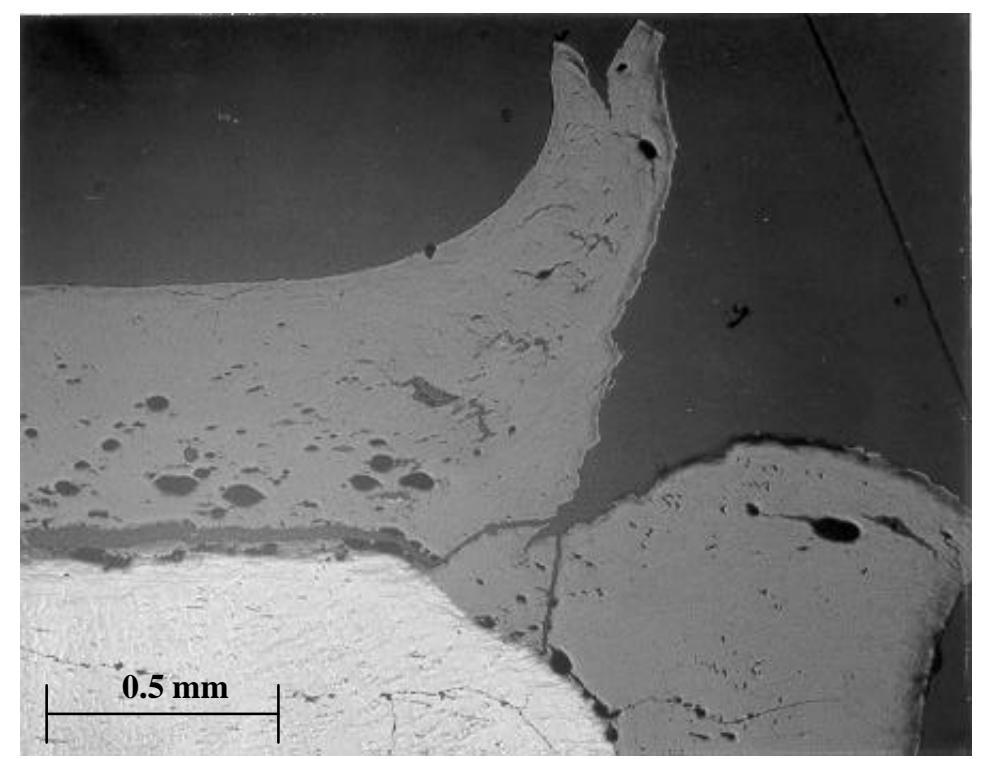

(a)

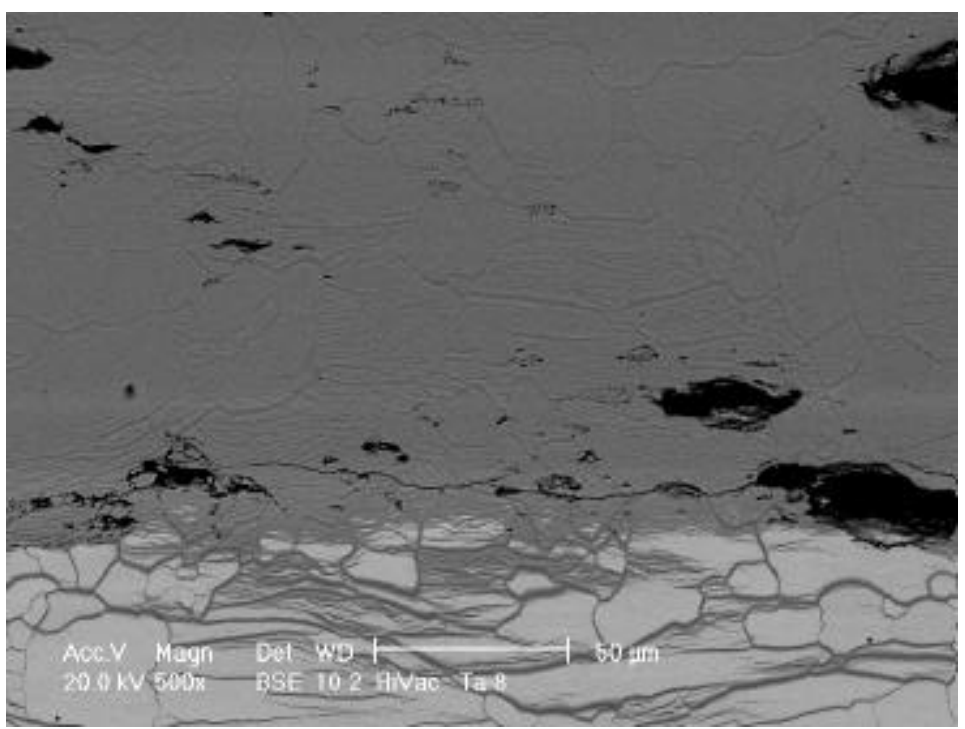

(b)

Figure 12. Cross section of oxide scale formed on T-222 specimen tested at $1200^{\circ} \mathrm{C}$. (a) Optical micrograph at 50X. (b) SEM of oxide to alloy interface at 500X magnification. 


\subsection{Phase Identification by XRD}

We performed x-ray diffraction (XRD) analyses of oxides from the 500, 700, 900, and $1200^{\circ} \mathrm{C}$ tests. The oxide scale was intact on the specimens tested at 500 and $1200^{\circ} \mathrm{C}$. Oxide powders were used for the analyses for the 700 and $900^{\circ} \mathrm{C}$ exposures. A pattern expressed for a solid solution, $\mathrm{Ta}(\mathrm{O})$, formed from tantalum heated in air and oxygen between 470 and $520^{\circ} \mathrm{C}$ provided the best fit for the $500^{\circ} \mathrm{C}$ test.[9] There were some unidentifiable peaks that could result from lattice distortion due to dissolved oxygen. They did not match patterns for metallic tantalum phases. Diffraction peaks became more distinct with higher temperatures. Other oxide patterns, e.g., $\mathrm{Ta}_{2} \mathrm{O}_{5}$, and $\mathrm{Ta}_{14.8} \mathrm{~W}_{1.20} \mathrm{O}_{40.6}$ provided fair fit to the peaks. The pentoxide pattern fit the spectrum from the $1200^{\circ} \mathrm{C}$ test quite well.

\subsection{Mobilization Rates Obtained from ICP-AES Measurements}

We present a summary of the mass flux determinations for tantalum, tungsten and hafnium from the ICP-AES measurements in Table 3. Detailed calculations for the mass flux are given in Appendix A. Although the reported flux values are derived from test chamber, the collection tube, and filter measurements, tungsten was the only element found in significant quantities beyond the test chamber. Hafnium was only detected within the test chamber at 600 and $700^{\circ} \mathrm{C}$. These were the only measurements for this element that were above the Engineering Maximum Flux Value (EMFV) as previously defined.[10] Tantalum measurements were well above detection limits except for those for the 1100 and $1200^{\circ} \mathrm{C}$ tests. The measurements were only 20 to 40 percent above the detection limit at these higher temperatures. The mass flux determinations for tungsten were always greater than ten times the uncertainty.

Table 3. Mass flux determinations from ICP-AES measurements.

\begin{tabular}{|c|c|c|c|c|}
\hline Temperature, ${ }^{\circ} \mathrm{C}$ & $\begin{array}{c}\text { Time, } \\
\mathrm{h}\end{array}$ & $\begin{array}{c}\mathrm{Hf} \\
\left(\mathrm{g} / \mathrm{m}^{2}-\mathrm{h}\right)\end{array}$ & $\begin{array}{c}\mathrm{Ta} \\
\left(\mathrm{g} / \mathrm{m}^{2}-\mathrm{h}\right)\end{array}$ & $\begin{array}{c}\mathrm{W} \\
\left(\mathrm{g} / \mathrm{m}^{2}-\mathrm{h}\right)\end{array}$ \\
\hline & & & & \\
\hline 500 & 81 & $2.38 \mathrm{E}-5$ & $1.12 \mathrm{E}-3$ & $1.89 \mathrm{E}-4$ \\
\hline 600 & 55 & $2.48 \mathrm{E}-4$ & $3.12 \mathrm{E}-2$ & $2.64 \mathrm{E}-3$ \\
\hline 700 & 55 & $7.13 \mathrm{E}-5$ & $1.30 \mathrm{E}-2$ & $4.10 \mathrm{E}-4$ \\
\hline 800 & 48 & $8.04 \mathrm{E}-5$ & $4.97 \mathrm{E}-3$ & $5.09 \mathrm{E}-4$ \\
\hline 900 & 8 & $2.40 \mathrm{E}-4$ & $5.76 \mathrm{E}-3$ & $2.67 \mathrm{E}-3$ \\
\hline 1000 & 6 & $3.22 \mathrm{E}-3$ & $4.04 \mathrm{E}-3$ & $4.54 \mathrm{E}-3$ \\
\hline 1100 & 4 & $4.82 \mathrm{E}-4$ & $2.41 \mathrm{E}-4$ & $5.03 \mathrm{E}-3$ \\
\hline 1200 & 2 & $9.63 \mathrm{E}-4$ & $4.81 \mathrm{E}-4$ & $1.16 \mathrm{E}-1$ \\
\hline
\end{tabular}

(a) The uncertainties for the mass flux measurements are given in the calculations in Appendix A. 


\section{DISCUSSION}

We have plotted the mass flux of tantalum and tungsten with respect to temperature in Figure 13. The value for tungsten is approximately one-tenth of that for tantalum at $600^{\circ} \mathrm{C}$ whereas the mass flux of hafnium from Table 3 is about two orders of magnitude lower than tantalum. These ratios correlate with those in the alloy suggesting that mobilization from the specimen was by oxide spalling. There was evidence that tungsten was also mobilized by another mechanism involving volatilization. One-third of the tungsten mobilized at $500^{\circ} \mathrm{C}$ was found deposited downstream from the test chamber. About half of the $\mathrm{W}$ mobilized was found downstream of the test chamber at $800^{\circ} \mathrm{C}$ and about 85 percent at $1200^{\circ} \mathrm{C}$. This higher relative migration of tungsten from the test chamber with increasing temperature and the visible evidence of a deposit on the filter from the $1200^{\circ} \mathrm{C}$ test show that migration was occurring by volatile species, i.e., $\mathrm{WO}_{3}$ polymers, as previously noted. The decrease in tantalum mobilization with temperature correlate with the amounts of powder that we observed for the various tests. Most notably was the lack of spalling or oxide scale exfoliation at the highest temperatures of 1100 and $1200^{\circ} \mathrm{C}$. These observations plus the fact that there was little indication of tantalum migration beyond the test chamber show that the particulate we characterized in Section 3.4 are not very susceptible to migration.

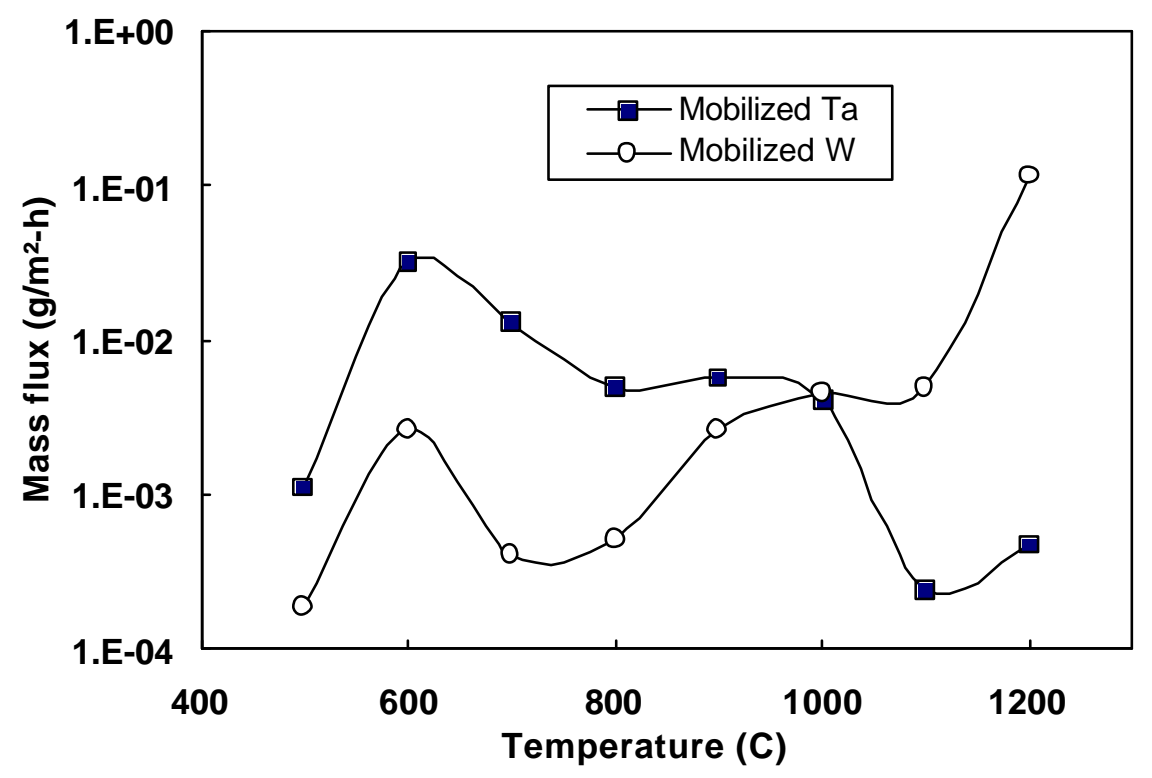

Figure 13. Mass flux of tantalum and tungsten from T-222 plotted with respect to temperature.

We compare the mass flux of tungsten and tantalum from the T-222 alloy with values from our previous study of air oxidation of a powder metallurgy (PM) product.[5] The PM product contained 95 and $0.1 \mathrm{wt} \%$ tungsten and tantalum, respectively. Figure 14 shows that the mass flux of tungsten for the two different studies was quite comparable at $500^{\circ} \mathrm{C}$ despite the fact that the T-222 alloy contained only one-tenth as much tungsten. The measurements from the T-222, however, are about two orders of magnitude lower above $800^{\circ} \mathrm{C}$. This agrees with the 
temperatures at which we observed the development and retention of significant oxide scale on T-222 alloy. Perhaps most of the $\mathrm{WO}_{3}$ volatilization occurred during the initial stages of the test before an oxide scale formed. Once a scale formed similar to those shown in Figure 3, the volatilization process was impeded. Plots for tantalum mass flux in Figure 15 show a different trend. The values of tantalum mobilization for the PM product with only $0.1 \mathrm{wt} \%$ Ta exceed those from T-222 above $800^{\circ} \mathrm{C}$. Considering the apparent link between tantalum mobilization and oxide spalling, results from the previous study[5] must be influenced by the spalling characteristics of the tungsten PM product.

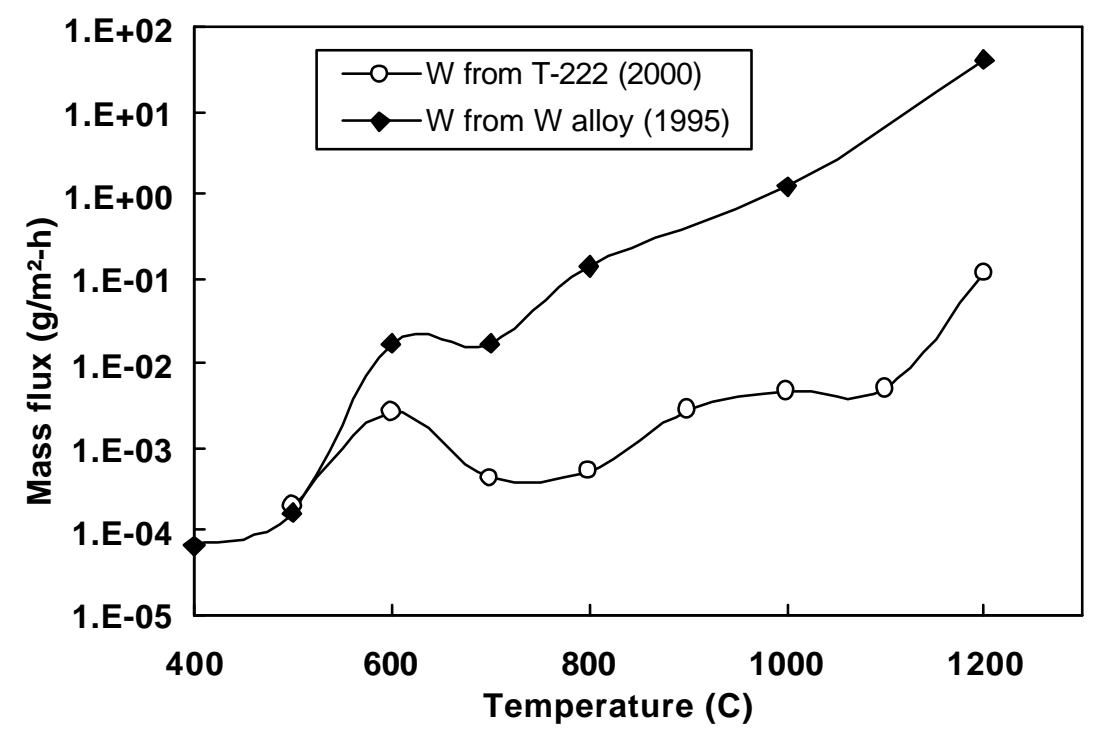

Figure 14. Mass flux of tungsten from T-222 alloy and a previously tested PM product containing $95 \mathrm{wt} \%$ tungsten.

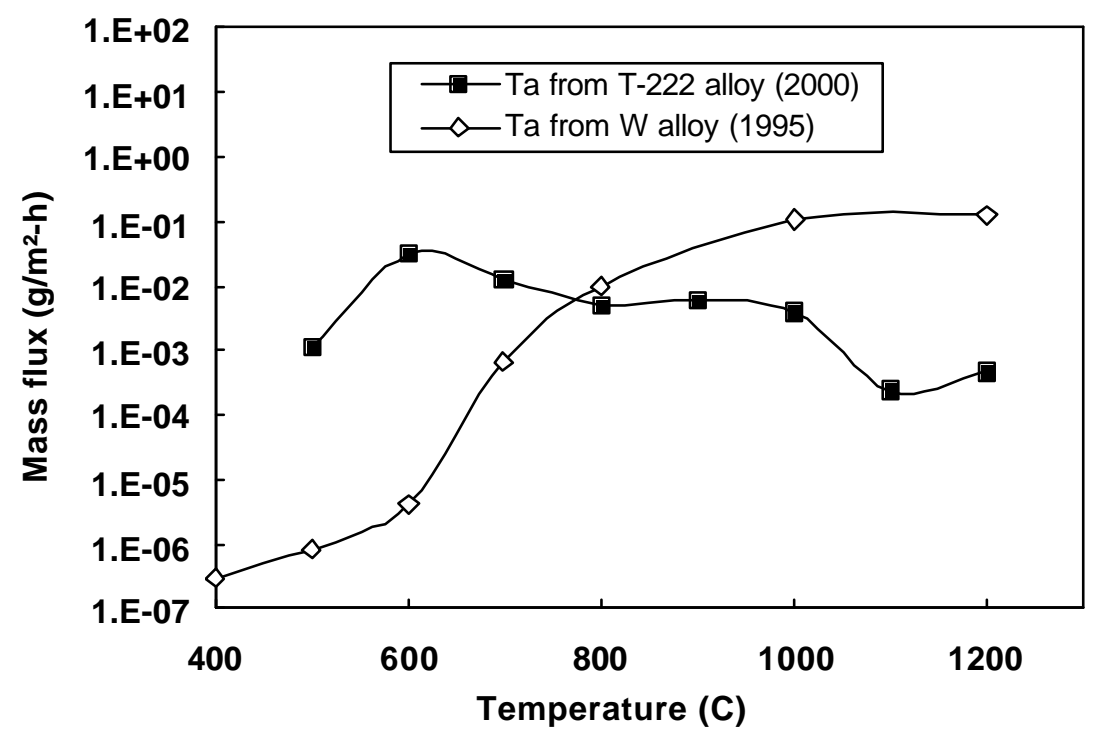

Figure 15. Mass flux of tantalum from T-222 alloy and a previously tested PM product containing only $0.1 \mathrm{wt} \%$ tantalum. 
We observed embrittlement from oxygen dissolution into the tantalum alloy. These were apparent from the cracks and increased hardness in the alloy shown in Figure 10, Figure 11, and Figure 12. The specimen tested at $1100^{\circ} \mathrm{C}$ also fractured in a very brittle mode when we tried to remove the oxide scale. These observations show that there should be an awareness of potential embrittlement of tantalum alloys if exposed to significant oxygen pressures and temperatures during an off-normal condition.

\section{CONCLUSIONS}

We have found that mobilization processes in tantalum alloy T-222 is linked to the character of the oxide. The development and growth of oxides on tantalum are complex and depend upon time, temperature and oxygen pressure. Oxide spalling appears to be a major contributor to the mobilization process. We observed a smaller yellowish particulate that we believed formed during exposures. This type of spalled particulate and the measurements of mobilized tantalum and hafnium are most abundant at 600 and $700^{\circ} \mathrm{C}$. Oxides appear to be sintered into a harder scale at higher temperatures. We believe that larger pieces of oxide scale and some particulate from near the oxide to metal interface are released during cool down. The oxide scales remained intact and very little particulate formation resulted from the highest temperature exposures at 1100 and $1200^{\circ} \mathrm{C}$. Although the mobilization of tantalum and hafnium is basically linked to spalled particulate we did not observe the transport of even the small, flake-like particles out of the test chamber.

Tungsten was mobilized not only by spalling but showed an increasing contribution from volatilization with increasing temperature. Volatilization played a significant role even at the lowest temperature of $500^{\circ} \mathrm{C}$. This may occur prior to the formation of the tantalum oxide scale. The mass flux at this temperature was actually very close to that which we observed from a previously tested powder metallurgy tungsten alloy. The volatilization of tungsten then actually decreases relative to its molar concentration in the alloy at higher temperatures. This suggests that an enhanced oxide scale slowed down the volatilization process of tungsten from the alloy.

We have determined mass flux values for tantalum, hafnium and tungsten from the T-222 alloy. These data could be used to estimate mobilization and activated product releases. However, since the processes are largely driven by oxidation spalling potential influences of thermal cycling with additional particulate formation should be kept in mind. We have also observed the effects of the dissolution of interstitial gas species into the tantalum alloy. This increased hardness and rendered some specimens quite brittle. This is an issue that should be considered in future applications of such alloys that could potentially be exposed to oxidizing conditions. 


\section{REFERENCES}

1. R. H. Cooper, Jr. and E. E. Hoffman, Refractory Alloy Technology for Space Nuclear Power Applications, CONF-8308130 (1984).

2. P.Kofstad, High-Temperature Oxidation of Metals, 190-209, John Wiley \& Sons, Inc., New York (1966).

3. R. Speiser and G. R St. Pierre, "Fundamentals of Refractory Metal-Gaseous Environmental Interaction," in The Science and Technology of Tungsten, Tantalum, Molybdenum, Niobium and Their Alloys, 289-330. Pergamon Press, New York (1964).

4 E. Gebhardt and R. Rothenbacher, "The Physical Properties of Refractory Metals with Reference to Other Engineering Materials," in The Science and Technology of Tungsten, Tantalum, Molybdenum, Niobium and Their Alloys, 157-173. Pergamon Press, New York (1964).

5 K. A. McCarthy, G. R. Smolik, D. L. Hagrman, and K. Coates, "Dose Due to Mobilization of Tungsten Products in Air," Fusion Technology, 1843-1846, (1996).

6. D. A. Petti, G. R. Smolik, and K. A. McCarthy, "Tungsten Mobilization During Steam Exposure Between 400 and $1200^{\circ}$ C," Proceedings of $20^{\text {th }}$ Symposium on Fusion Technology, September 9-11, 1998, Marseille, France, 1483-1486.

7 D. R. Lide, ed., CRC Handbook of Chemistry and Physics, CRC Press, (1994) p. 4-104.

8. K. Hauffe, Oxidation of Metals, 236-240, Plenum Press, New York (1965).

9 N. Terao, "Structure des Oxides de Tantale," Japanese. Journal of Applied Physics, 6, 21-34 (1967).

10 S. C. Wilkins, Mobilization Tests-Data Base Uncertainties, Fusion Safety EDF No. ITER/US/94/TE/SA-17. September 1994. 
APPENDIX A

ICP-AES ANALYSES AND

MASS FLUX CALCULATIONS

FOR ELEMENTS MOBILIZED FROM

TANTALUM ALLOY T-222 
Ta1: Tested at $500^{\circ} \mathrm{C}$ for 81 hours in air $(1000 \mathrm{sccm}$ flow rate)

\begin{tabular}{|c|c|c|c|c|c|c|c|c|c|}
\hline & & & & Co & $\mathrm{Hf}$ & $\mathrm{Ta}$ & W & & \\
\hline Specimen Ta1 & & & & wavelenght & wavelenght & wavelenght & wavelenght & & \\
\hline (Date of Anal.) & Conditions & & Component & 228.6 & 282.0 & 263.5 & 207.9 & & \\
\hline \multicolumn{10}{|c|}{ 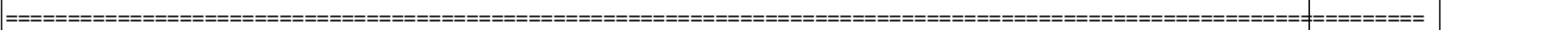 } \\
\hline \multicolumn{2}{|c|}{ For Data analyzed on 9-19-00, } & $\%$ SD of Cal. Stds & sigma \% & 10.4 & 3.2 & 5.4 & 4.2 & & \\
\hline \multicolumn{2}{|c|}{ 9-27-00, 10-2-00,10-09- } & SD of Blk Std & sigma prime $\mathrm{ug} / \mathrm{ml}$ & 0.002 & 0.020 & 0.007 & 0.006 & & \\
\hline \multicolumn{10}{|l|}{ Ŝpecimen } \\
\hline \multirow[t]{2}{*}{ Ta1 } & $500 \mathrm{C} / 81$ hours & & & & & & & & \\
\hline & Air & A & RXN tube(set $\mathrm{J}$ )ug/ml & & -0.012 & 2.822 & 0.363 & & \\
\hline \multirow[t]{2}{*}{ Time, $\mathrm{h}$} & $05 / 15 / 2000$ & $B$ & Col. tube,(Set 14) ug/ml & & -0.043 & -0.011 & 0.058 & & \\
\hline & & C & QW filter,ug/ml & & 0.011 & -0.001 & 0.092 & & \\
\hline \multirow[t]{3}{*}{81} & & $(A+B+C)$ & subtotal, ug & & -2.200 & 140.500 & 25.650 & & \\
\hline & & & \pm ug & & 0.147 & 15.239 & 1.592 & & \\
\hline & & a (RXN) & Ta1 RXN FB, ug/ml & & 0.011 & 0.012 & 0.002 & & \\
\hline \multirow[t]{2}{*}{ Notes: } & & $\mathrm{b}(\mathrm{Col} \mathrm{T})$ & Ta1 CT FB, ug/ml & & -0.001 & -0.013 & 0.023 & & \\
\hline & & c (QW blank) & QW mean, ug/ml & & 0.030 & 0.001 & 0.012 & & \\
\hline \multicolumn{2}{|c|}{ 1) All $50 \mathrm{ml}$ aloqoits. } & $(a+b+c)$ & subtotal, ug & & 2.000 & 0.000 & 1.850 & & \\
\hline & & & \pm ug & & 3.464 & 1.212 & 1.039 & & \\
\hline & & $(A+B+C)-(a+b+c)$ & Total, ug & & -4.200 & 140.500 & 23.800 & & \\
\hline & & & \pm ug & & 3.467 & 15.287 & 1.901 & & \\
\hline & & $\mathrm{DL}\left(3^{*} \mathrm{SD}\right)$ & $\mathrm{ug} / \mathrm{ml}$ & & 0.060 & 0.021 & 0.018 & & \\
\hline & & $\mathrm{DL}\left(3^{*} \mathrm{SD}\right)$ & ug & & 3.000 & 1.050 & 0.900 & & \\
\hline & & \multicolumn{2}{|c|}{ Total Corrected for DL } & & 3.000 & 140.500 & 23.800 & & Total \\
\hline & & & & & & & & & $\mathrm{g} / \mathrm{m} 2-\mathrm{h}$ \\
\hline & \multicolumn{2}{|c|}{ As calculated flux values: } & Mass Flux, g/m2-h & & $2.38 \mathrm{E}-05$ & $1.12 \mathrm{E}-03$ & $1.89 \mathrm{E}-04$ & & 1.33E-03 \\
\hline & & & $\pm \mathrm{g} / \mathrm{m} 2-\mathrm{h}$ & & 2.75E-05 & $1.21 \mathrm{E}-04$ & $1.51 \mathrm{E}-05$ & & g \\
\hline & & & $\pm \%$ & & 115.57 & 10.88 & 7.99 & & 1.67E-04 \\
\hline & \multicolumn{2}{|c|}{ Flux values with Eng.Judgement: } & Mass Flux, g/m2-h & & $2.38 \mathrm{E}-05$ & $1.12 \mathrm{E}-03$ & $1.89 \mathrm{E}-04$ & & \\
\hline & \multicolumn{2}{|c|}{ Errors not applicable } & $\pm g / m 2-h$ & & $2.75 \mathrm{E}-05$ & $1.21 \mathrm{E}-04$ & $1.51 \mathrm{E}-05$ & & \\
\hline & & & $\pm \%$ & & 115.57 & 10.88 & 7.99 & & \\
\hline & & & & & & & & & \\
\hline \multicolumn{10}{|l|}{ Specimen: Ta1 } \\
\hline & Dimensions: & $\mathrm{t}$ avg, $\mathrm{cm}$ & $\mathrm{h}$ avg., $\mathrm{cm}$ & w avg., cm & & & & & \\
\hline & & 0.2690 & 2.5420 & 2.5232 & & & & & \\
\hline & Area, m2 & 0.001555 & & & & & & & \\
\hline & weight, $\mathrm{g}$ & 28.6025 & & & & & & & \\
\hline
\end{tabular}


Ta2: Tested at $600^{\circ} \mathrm{C}$ for 55 hours in air $(1000 \mathrm{sccm}$ flow rate)

\begin{tabular}{|c|c|c|c|c|c|c|c|c|c|}
\hline & & & & Co & $\mathrm{Hf}$ & $\mathrm{Ta}$ & $\mathrm{W}$ & & \\
\hline Specimen Ta2 & & & & wavelenght & wavelenght & wavelenght & wavelenght & & \\
\hline (Date of Anal.) & Conditions & & Component & 228.6 & 282.0 & 263.5 & 207.9 & & \\
\hline$==============$ & $===========$ & $===============$ & & & & & & $=========$ & \\
\hline \multicolumn{2}{|c|}{ For Data analyzed on 9-19-00, } & $\%$ SD of Cal. Stds & sigma \% & 10.4 & 3.2 & 5.4 & 4.2 & & \\
\hline \multicolumn{2}{|c|}{$9-27-00,10-2-00,10-09-$} & SD of Blk Std & sigma prime $\mathrm{ug} / \mathrm{ml}$ & 0.002 & 0.020 & 0.007 & 0.006 & & \\
\hline \multicolumn{10}{|l|}{ Ŝpecimen } \\
\hline \multirow[t]{2}{*}{ Ta2 } & $600 \mathrm{C} / 55$ hours & & & & & & & & \\
\hline & Air & A & RXN tube(no ID)ug/ml & & 0.482 & 53.410 & 4.544 & & \\
\hline \multirow[t]{2}{*}{ Time, $\mathrm{h}$} & 05/23/2000 & B & Col. tube,(Set 12) ug/ml & & -0.034 & -0.008 & 0.016 & & \\
\hline & & C & QW filter,ug/ml & & -0.024 & 0.034 & -0.002 & & \\
\hline \multirow[t]{3}{*}{55} & & $(A+B+C)$ & subtotal, ug & & 21.200 & 2671.800 & 227.900 & & \\
\hline & & & \pm ug & & 1.548 & 288.414 & 19.085 & & \\
\hline & & $a(R X N)$ & Ta2 RXN FB, ug/ml & & -0.016 & 0.007 & 0.016 & & \\
\hline \multirow[t]{2}{*}{ Notes: } & & $\mathrm{b}(\mathrm{Col} \mathrm{T})$ & Ta2 CT FB, ug/ml & & -0.014 & -0.005 & 0.013 & & \\
\hline & & c (QW blank) & QW mean, ug/ml & & 0.030 & 0.001 & 0.012 & & \\
\hline \multicolumn{2}{|c|}{ 1) All $50 \mathrm{ml}$ aloqoits. } & $(a+b+c)$ & subtotal, ug & & 0.000 & 0.150 & 2.050 & & \\
\hline & & & \pm ug & & 3.464 & 1.212 & 1.039 & & \\
\hline & & $(A+B+C)-(a+b+c)$ & Total, ug & & 21.200 & 2671.650 & 225.850 & & \\
\hline & & & \pm ug & & 3.794 & 288.417 & 19.113 & & \\
\hline & & $\mathrm{DL}\left(3^{*} \mathrm{SD}\right)$ & $\mathrm{ug} / \mathrm{ml}$ & & 0.060 & 0.021 & 0.018 & & \\
\hline & & $\mathrm{DL}\left(3^{*} \mathrm{SD}\right)$ & ug & & 3.000 & 1.050 & 0.900 & & \\
\hline & & & & & & & & & \\
\hline & & \multicolumn{2}{|c|}{ Total Corrected for DL } & & 21.200 & 2671.650 & 225.850 & & Total \\
\hline & & & & & & & & & g/m2-h \\
\hline & \multicolumn{2}{|c|}{ As calculated flux values: } & Mass Flux, g/m2-h & & $2.48 \mathrm{E}-04$ & $3.12 \mathrm{E}-02$ & $2.64 \mathrm{E}-03$ & & $3.41 \mathrm{E}-02$ \\
\hline & & & $\pm \mathrm{g} / \mathrm{m} 2-\mathrm{h}$ & & 4.44E-05 & 3.37E-03 & $2.23 \mathrm{E}-04$ & & $g$ \\
\hline & & & $\pm \%$ & & 17.90 & 10.80 & 8.46 & & $2.92 \mathrm{E}-03$ \\
\hline & \multicolumn{2}{|c|}{ Flux values with Eng.Judgement: } & Mass Flux, g/m2-h & & $2.48 \mathrm{E}-04$ & $3.12 \mathrm{E}-02$ & $2.64 \mathrm{E}-03$ & & \\
\hline & \multicolumn{2}{|c|}{ Errors not applicable } & $\pm \mathrm{g} / \mathrm{m} 2-\mathrm{h}$ & & 4.44E-05 & 3.37E-03 & $2.23 E-04$ & & \\
\hline & & & $\pm \%$ & & 17.90 & 10.80 & 8.46 & & \\
\hline & & & & & & & & & \\
\hline \multicolumn{10}{|l|}{ Specimen: Ta2 } \\
\hline & Dimensions: & $\mathrm{t}$ avg, $\mathrm{cm}$ & $\mathrm{h}$ avg., $\mathrm{cm}$ & w avg., $\mathrm{cm}$ & & & & & \\
\hline & & 0.2694 & 2.5415 & 2.5225 & & & & & \\
\hline & Area, $\mathrm{m} 2$ & 0.001555 & & & & & & & \\
\hline & weight, $\mathrm{g}$ & 28.8577 & & & & & & & \\
\hline
\end{tabular}


Ta3: Tested at $700^{\circ} \mathrm{C}$ for 55 hours in air $(1000 \mathrm{sccm}$ flow rate)

\begin{tabular}{|c|c|c|c|c|c|c|c|c|c|}
\hline & & & & Co & $\mathrm{Hf}$ & $\mathrm{Ta}$ & W & & \\
\hline Specimen Ta3 & & & & wavelenght & wavelenght & wavelenght & wavelenght & & \\
\hline (Date of Anal.) & Conditions & & Component & 228.6 & 282.0 & 263.5 & 207.9 & & \\
\hline \multicolumn{2}{|c|}{ 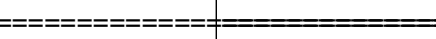 } & $================$ & & & & & & $=========$ & \\
\hline \multicolumn{2}{|c|}{ For Data analyzed on 9-19-00, } & $\%$ SD of Cal. Stds & sigma \% & 10.4 & 3.2 & 5.4 & 4.2 & & \\
\hline \multicolumn{2}{|c|}{ 9-27-00, 10-2-00,10-09- } & SD of Blk Std & sigma prime $\mathrm{ug} / \mathrm{ml}$ & 0.002 & 0.020 & 0.007 & 0.006 & & \\
\hline \multicolumn{10}{|l|}{ Ŝpecimen } \\
\hline \multirow[t]{2}{*}{ Ta3 } & $700 \mathrm{C} / 55$ hours & & & & & & & & \\
\hline & Air & A & RXN tube(no ID)ug/ml & & 0.177 & 22.260 & 0.444 & & \\
\hline \multirow[t]{2}{*}{ Time, $\mathrm{h}$} & 05/30/2000 & B & Col. tube,(Set 12) ug/ml & & -0.010 & 0.003 & 0.268 & & \\
\hline & & C & QW filter,ug/ml & & 0.029 & 0.025 & 0.025 & & \\
\hline \multirow[t]{3}{*}{55} & & $(A+B+C)$ & subtotal, ug & & 9.800 & 1114.400 & 36.850 & & \\
\hline & & & \pm ug & & 0.575 & 120.204 & 2.181 & & \\
\hline & & $\mathrm{a}(\mathrm{RXN})$ & Ta3 RXN FB, ug/ml & & 0.059 & 0.021 & 0.009 & & \\
\hline \multirow[t]{2}{*}{ Notes: } & & $\mathrm{b}(\mathrm{Col} \mathrm{T})$ & Ta3 CT FB, ug/ml & & -0.015 & -0.006 & 0.014 & & \\
\hline & & c (QW blank) & QW mean, ug/ml & & 0.030 & 0.001 & 0.012 & & \\
\hline \multicolumn{2}{|c|}{ 1) All $50 \mathrm{ml}$ aloqoits. } & $(a+b+c)$ & subtotal, ug & & 3.700 & 0.800 & 1.750 & & \\
\hline & & & \pm ug & & 3.464 & 1.212 & 1.039 & & \\
\hline & & $(A+B+C)-(a+b+c)$ & Total, ug & & 6.100 & 1113.600 & 35.100 & & \\
\hline & & & $\pm \mathrm{ug}$ & & 3.511 & 120.210 & 2.416 & & \\
\hline & & $\mathrm{DL}\left(3^{*} \mathrm{SD}\right)$ & $\mathrm{ug} / \mathrm{ml}$ & & 0.060 & 0.021 & 0.018 & & \\
\hline & & $\mathrm{DL}\left(3^{\star} \mathrm{SD}\right)$ & ug & & 3.000 & 1.050 & 0.900 & & \\
\hline & & \multicolumn{2}{|c|}{ Total Corrected for DL } & & 6.100 & 1113.600 & 35.100 & & Total \\
\hline & & & & & & & & & g/m2-h \\
\hline & \multicolumn{2}{|c|}{ As calculated flux values: } & Mass Flux, g/m2-h & & 7.13E-05 & $1.30 \mathrm{E}-02$ & $4.10 \mathrm{E}-04$ & & 1.35E-02 \\
\hline & & & $\pm \mathrm{g} / \mathrm{m} 2-\mathrm{h}$ & & $4.10 \mathrm{E}-05$ & $1.40 \mathrm{E}-03$ & $2.82 \mathrm{E}-05$ & & $g$ \\
\hline & & & $\pm \%$ & & 57.57 & 10.79 & 6.88 & & $1.15 \mathrm{E}-03$ \\
\hline & \multicolumn{2}{|c|}{ Flux values with Eng.Judgement: } & Mass Flux, g/m2-h & & $7.13 \mathrm{E}-05$ & $1.30 \mathrm{E}-02$ & $4.10 \mathrm{E}-04$ & & \\
\hline & \multicolumn{2}{|c|}{ Errors not applicable } & $\pm \mathrm{g} / \mathrm{m} 2-\mathrm{h}$ & & 4.10E-05 & $1.40 \mathrm{E}-03$ & $2.82 \mathrm{E}-05$ & & \\
\hline & & & $\pm \%$ & & 57.57 & 10.79 & 6.88 & & \\
\hline \multicolumn{10}{|l|}{ Specimen: Ta3 } \\
\hline & Dimensions: & $\mathrm{t}$ avg, $\mathrm{cm}$ & $\mathrm{h}$ avg., $\mathrm{cm}$ & w avg., $\mathrm{cm}$ & & & & & \\
\hline & & 0.2694 & 2.5433 & 2.5225 & & & & & \\
\hline & Area, m2 & 0.001556 & & & & & & & \\
\hline & weight, g & 28.7979 & & & & & & & \\
\hline
\end{tabular}


Ta4: Tested at $800^{\circ} \mathrm{C}$ for 48 hours in air $(1000$ sccm flow rate)

\begin{tabular}{|c|c|c|c|c|c|c|c|c|c|}
\hline & & & & Co & $\mathrm{Hf}$ & $\mathrm{Ta}$ & W & & \\
\hline Specimen Ta4 & & & & wavelenght & wavelenght & wavelenght & wavelenght & & \\
\hline (Date of Anal.) & Conditions & & Component & 228.6 & 282.0 & 263.5 & 207.9 & & \\
\hline$==============1$ & $=$ & $================$ & & & & & & $=========$ & \\
\hline \multicolumn{2}{|c|}{ For Data analyzed on 9-19-00, } & $\%$ SD of Cal. Stds & sigma \% & 10.4 & 3.2 & 5.4 & 4.2 & & \\
\hline \multicolumn{2}{|c|}{ 9-27-00, 10-2-00,10-09- } & SD of Blk Std & sigma prime $\mathrm{ug} / \mathrm{ml}$ & 0.002 & 0.020 & 0.007 & 0.006 & & \\
\hline \multicolumn{10}{|l|}{ Ŝ́pecimen } \\
\hline \multirow[t]{2}{*}{ Ta4 } & $800 \mathrm{C} / 48$ hours & & & & & & & & \\
\hline & Air & A & RXN tube(no ID)ug/ml & & 0.045 & 7.394 & 0.391 & & \\
\hline \multirow[t]{2}{*}{ Time, $\mathrm{h}$} & 08/01/2000 & B & Col. tube,(Set 12) ug/ml & & 0.006 & 0.005 & 0.043 & & \\
\hline & & C & QW filter,ug/ml & & 0.037 & 0.019 & 0.370 & & \\
\hline \multirow[t]{3}{*}{48} & & $(A+B+C)$ & subtotal, ug & & 4.400 & 370.900 & 40.200 & & \\
\hline & & & \pm ug & & 0.187 & 39.928 & 2.268 & & \\
\hline & & $a(\mathrm{RXN})$ & Ta4 RXN FB, ug/ml & & -0.021 & 0.002 & 0.018 & & \\
\hline \multirow[t]{2}{*}{ Notes: } & & $\mathrm{b}(\mathrm{Col} \mathrm{T})$ & Ta4 CT FB, ug/ml & & -0.041 & 0.001 & 0.014 & & \\
\hline & & c (QW blank) & QW mean, ug/ml & & 0.030 & 0.001 & 0.012 & & \\
\hline \multicolumn{2}{|c|}{ 1) All $50 \mathrm{ml}$ aloqoits. } & $(a+b+c)$ & subtotal, ug & & -1.600 & 0.200 & 2.200 & & \\
\hline & & & \pm ug & & 3.464 & 1.212 & 1.039 & & \\
\hline & & $(A+B+C)-(a+b+c)$ & Total, ug & & 6.000 & 370.700 & 38.000 & & \\
\hline & & & \pm ug & & 3.469 & 39.946 & 2.495 & & \\
\hline & & $\mathrm{DL}\left(3^{*} \mathrm{SD}\right)$ & $\mathrm{ug} / \mathrm{ml}$ & & 0.060 & 0.021 & 0.018 & & \\
\hline & & $\mathrm{DL}\left(3^{*} \mathrm{SD}\right)$ & ug & & 3.000 & 1.050 & 0.900 & & \\
\hline & & \multicolumn{2}{|c|}{ Total Corrected for DL } & & 6.000 & 370.700 & 38.000 & & Total \\
\hline & & & & & & & & & g/m2-h \\
\hline & \multicolumn{2}{|c|}{ As calculated flux values: } & Mass Flux, g/m2-h & & 8.04E-05 & 4.97E-03 & 5.09E-04 & & $5.56 \mathrm{E}-03$ \\
\hline & & & $\pm \mathrm{g} / \mathrm{m} 2-\mathrm{h}$ & & 4.65E-05 & 5.35E-04 & 3.34E-05 & & g \\
\hline & & & $\pm \%$ & & 57.82 & 10.78 & 6.57 & & $4.15 \mathrm{E}-04$ \\
\hline & \multicolumn{2}{|c|}{ Flux values with Eng.Judgement: } & Mass Flux, g/m2-h & & $8.04 \mathrm{E}-05$ & 4.97E-03 & $5.09 \mathrm{E}-04$ & & \\
\hline & \multicolumn{2}{|c|}{ Errors not applicable } & $\pm \mathrm{g} / \mathrm{m} 2-\mathrm{h}$ & & $4.65 \mathrm{E}-05$ & 5.35E-04 & 3.34E-05 & & \\
\hline & & & $\pm \%$ & & 57.82 & 10.78 & 6.57 & & \\
\hline & & & & & & & & & \\
\hline \multicolumn{10}{|l|}{ Specimen: Ta4 } \\
\hline & Dimensions: & $\mathrm{t}$ avg, $\mathrm{cm}$ & $\mathrm{h}$ avg., $\mathrm{cm}$ & w avg., $\mathrm{cm}$ & & & & & \\
\hline & & 0.2694 & 2.5232 & 2.5408 & & & & & \\
\hline & Area, m2 & 0.001555 & & & & & & & \\
\hline & weight, $\mathrm{g}$ & 28.8238 & & & & & & & \\
\hline
\end{tabular}


Ta5: Tested at $900^{\circ} \mathrm{C}$ for 8 hours in air $(1000 \mathrm{sccm}$ flow rate)

\begin{tabular}{|c|c|c|c|c|c|c|c|c|c|}
\hline & & & & Co & $\mathrm{Hf}$ & $\mathrm{Ta}$ & W & & \\
\hline Specimen Ta5 & & & & wavelenght & wavelenght & wavelenght & wavelenght & & \\
\hline (Date of Anal.) & Conditions & & Component & 228.6 & 282.0 & 263.5 & 207.9 & & \\
\hline$=============$ 柆 & & $==============$ & & & & & & $=========$ & \\
\hline \multicolumn{2}{|c|}{ For Data analyzed on 9-19-00, } & $\%$ SD of Cal. Stds & sigma \% & 10.4 & 3.2 & 5.4 & 4.2 & & \\
\hline \multicolumn{2}{|c|}{ 9-27-00, 10-2-00,10-09- } & SD of Blk Std & sigma prime $\mathrm{ug} / \mathrm{ml}$ & 0.002 & 0.020 & 0.007 & 0.006 & & \\
\hline \multicolumn{10}{|l|}{ Ŝpecimen } \\
\hline \multirow[t]{2}{*}{ Ta5 } & $900 \mathrm{C} / 8$ hours & & & & & & & & \\
\hline & Air & A & RXN tube(no ID)ug/ml & & 0.017 & 1.435 & 0.168 & & \\
\hline \multirow[t]{2}{*}{ Time, $\mathrm{h}$} & $08 / 08 / 2000$ & B & Col. tube,(Set 12) ug/ml & & 0.018 & 0.005 & 0.155 & & \\
\hline & & C & QW filter,ug/ml & & 0.031 & 0.001 & 0.355 & & \\
\hline \multirow[t]{3}{*}{8} & & $(A+B+C)$ & subtotal, ug & & 3.300 & 72.050 & 33.900 & & \\
\hline & & & \pm ug & & 0.127 & 7.749 & 1.773 & & \\
\hline & & $a(R X N)$ & Ta5 RXN FB, ug/ml & & 0.021 & 0.003 & -0.003 & & \\
\hline \multirow[t]{2}{*}{ Notes: } & & $\mathrm{b}(\mathrm{Col} \mathrm{T})$ & Ta5 CT FB, ug/ml & & -0.015 & -0.001 & 0.001 & & \\
\hline & & c (QW blank) & QW mean, ug/ml & & 0.030 & 0.001 & 0.012 & & \\
\hline \multicolumn{2}{|c|}{ 1) All $50 \mathrm{ml}$ aloqoits. } & $(a+b+c)$ & subtotal, ug & & 1.800 & 0.150 & 0.500 & & \\
\hline & & & \pm ug & & 3.464 & 1.212 & 1.039 & & \\
\hline & & $(A+B+C)-(a+b+c)$ & Total, ug & & 1.500 & 71.900 & 33.400 & & \\
\hline & & & \pm ug & & 3.466 & 7.843 & 2.055 & & \\
\hline & & $\mathrm{DL}\left(3^{*} \mathrm{SD}\right)$ & $\mathrm{ug} / \mathrm{ml}$ & & 0.060 & 0.021 & 0.018 & & \\
\hline & & $\mathrm{DL}\left(3^{*} \mathrm{SD}\right)$ & ug & & 3.000 & 1.050 & 0.900 & & \\
\hline & & & & & & & & & \\
\hline & & \multicolumn{2}{|c|}{ Total Corrected for DL } & & 3.000 & 71.900 & 33.400 & & Total \\
\hline & & & & & & & & & $g / m 2-h$ \\
\hline & \multicolumn{2}{|c|}{ As calculated flux values: } & Mass Flux, g/m2-h & & $2.40 \mathrm{E}-04$ & $5.76 \mathrm{E}-03$ & 2.67E-03 & & 8.67E-03 \\
\hline & & & $\pm \mathrm{g} / \mathrm{m} 2-\mathrm{h}$ & & $2.78 \mathrm{E}-04$ & $6.28 \mathrm{E}-04$ & $1.65 \mathrm{E}-04$ & & g \\
\hline & & & $\pm \%$ & & 115.55 & 10.91 & 6.15 & & $1.08 \mathrm{E}-04$ \\
\hline & & & & & & & & & \\
\hline & \multicolumn{2}{|c|}{ Flux values with Eng.Judgement: } & Mass Flux, g/m2-h & & $2.40 \mathrm{E}-04$ & $5.76 \mathrm{E}-03$ & $2.67 \mathrm{E}-03$ & & \\
\hline & \multicolumn{2}{|c|}{ Errors not applicable } & $\pm \mathrm{g} / \mathrm{m} 2-\mathrm{h}$ & & $2.78 \mathrm{E}-04$ & $6.28 \mathrm{E}-04$ & $1.65 \mathrm{E}-04$ & & \\
\hline & & & $\pm \%$ & & 115.55 & 10.91 & 6.15 & & \\
\hline & & $\overline{\bar{E}}$ & & & & & & & \\
\hline \multicolumn{10}{|l|}{ Specimen: Ta5 } \\
\hline & Dimensions: & $\mathrm{t}$ avg, $\mathrm{cm}$ & $\mathrm{h}$ avg., $\mathrm{cm}$ & w avg., $\mathrm{cm}$ & & & & & \\
\hline & & 0.2696 & 2.5263 & 2.5476 & & & & & \\
\hline & Area, m2 & 0.001561 & & & & & & & \\
\hline & weight, g & 28.9162 & & & & & & & \\
\hline
\end{tabular}


Ta6: Tested at $1000^{\circ} \mathrm{C}$ for 6 hours in air $(1000 \mathrm{sccm}$ flow rate)

\begin{tabular}{|c|c|c|c|c|c|c|c|c|c|}
\hline & & & & Co & $\mathrm{Hf}$ & $\mathrm{Ta}$ & W & & \\
\hline Specimen Ta6 & & & & wavelenght & wavelenght & wavelenght & wavelenght & & \\
\hline (Date of Anal.) & Conditions & & Component & 228.6 & 282.0 & 263.5 & 207.9 & & \\
\hline$==============$ & $=============$ & $===============$ & & & & $==========$ & & $=========$ & \\
\hline \multicolumn{2}{|c|}{ For Data analyzed on 9-19-00, } & $\%$ SD of Cal. Stds & sigma $\%$ & 10.4 & 3.2 & 5.4 & 4.2 & & \\
\hline \multicolumn{2}{|c|}{ 9-27-00, 10-2-00,10-09- } & SD of Blk Std & sigma prime $\mathrm{ug} / \mathrm{ml}$ & 0.002 & 0.020 & 0.007 & 0.006 & & \\
\hline \multicolumn{10}{|l|}{ Ŝpecimen } \\
\hline \multirow[t]{2}{*}{ Ta6 } & $1000 \mathrm{C} / 6$ hours & & & & & & & & \\
\hline & Air & A & RXN tube(no ID)ug/ml & & 0.010 & 0.723 & 0.536 & & \\
\hline \multirow[t]{2}{*}{ Time, $\mathrm{h}$} & $08 / 10 / 2000$ & $\mathrm{~B}$ & Col. tube,(Set 12) ug/ml & & -0.030 & 0.040 & 0.018 & & \\
\hline & & C & QW filter,ug/ml & & -0.001 & -0.001 & 0.325 & & \\
\hline \multirow[t]{3}{*}{6} & & $(A+B+C)$ & subtotal, ug & & -1.050 & 38.100 & 43.950 & & \\
\hline & & & \pm ug & & 0.101 & 3.910 & 2.634 & & \\
\hline & & a $(\mathrm{RXN})$ & Ta6 RXN FB, ug/ml & & 0.045 & 0.001 & 0.006 & & \\
\hline \multirow[t]{2}{*}{ Notes: } & & $\mathrm{b}(\mathrm{Col} \mathrm{T})$ & Ta6 CT FB, ug/ml & & 0.005 & 0.007 & 0.014 & & \\
\hline & & c (QW blank) & QW mean, ug/ml & & 0.030 & 0.001 & 0.012 & & \\
\hline \multicolumn{2}{|c|}{ 1) All $50 \mathrm{ml}$ aloqoits. } & $(a+b+c)$ & subtotal, ug & & 4.000 & 0.450 & 1.600 & & \\
\hline & & & \pm ug & & 3.464 & 1.212 & 1.039 & & \\
\hline & & $(A+B+C)-(a+b+c)$ & Total, ug & & -5.050 & 37.650 & 42.350 & & \\
\hline & & & \pm ug & & 3.466 & 4.094 & 2.831 & & \\
\hline & & $\mathrm{DL}\left(3^{*} \mathrm{SD}\right)$ & $\mathrm{ug} / \mathrm{ml}$ & & 0.060 & 0.021 & 0.018 & & \\
\hline & & DL (3*SD) & ug & & 3.000 & 1.050 & 0.900 & & \\
\hline & & \multicolumn{2}{|c|}{ Total Corrected for DL } & & 3.000 & 37.650 & 42.350 & & Total \\
\hline & & & & & & & & & g/m2-h \\
\hline & \multicolumn{2}{|c|}{ As calculated flux values: } & Mass Flux, g/m2-h & & 3.22E-04 & $4.04 \mathrm{E}-03$ & $4.54 \mathrm{E}-03$ & & $8.91 \mathrm{E}-03$ \\
\hline & & & $\pm \mathrm{g} / \mathrm{m} 2-\mathrm{h}$ & & 3.72E-04 & 4.39E-04 & 3.04E-04 & & g \\
\hline & & & $\pm \%$ & & 115.52 & 10.87 & 6.69 & & $8.30 \mathrm{E}-05$ \\
\hline & \multicolumn{2}{|c|}{ Flux values with Eng.Judgement: } & Mass Flux, g/m2-h & & $3.22 \mathrm{E}-04$ & $4.04 \mathrm{E}-03$ & 4.54E-03 & & \\
\hline & \multicolumn{2}{|c|}{ Errors not applicable } & $\pm \mathrm{g} / \mathrm{m} 2-\mathrm{h}$ & & 3.72E-04 & 4.39E-04 & 3.04E-04 & & \\
\hline & & & $\pm \%$ & & 115.52 & 10.87 & 6.69 & & \\
\hline \multicolumn{10}{|l|}{ Specimen: Ta6 } \\
\hline & Dimensions: & $\mathrm{t}$ avg, $\mathrm{cm}$ & $\mathrm{h}$ avg., $\mathrm{cm}$ & w avg., $\mathrm{cm}$ & & & & & \\
\hline & & 0.2692 & 2.5235 & 2.5377 & & & & & \\
\hline & Area, $\mathrm{m} 2$ & 0.001553 & & & & & & & \\
\hline & weight, $\mathrm{g}$ & 28.8064 & & & & & & & \\
\hline
\end{tabular}


Ta7: Tested at $1100^{\circ} \mathrm{C}$ for 4 hours in air $(1000 \mathrm{sccm}$ flow rate)

\begin{tabular}{|c|c|c|c|c|c|c|c|c|c|}
\hline & & & & Co & $\mathrm{Hf}$ & $\mathrm{Ta}$ & W & & \\
\hline Specimen Ta7 & & & & wavelenght & wavelenght & wavelenght & wavelenght & & \\
\hline (Date of Anal.) & Conditions & & Component & 228.6 & 282.0 & 263.5 & 207.9 & & \\
\hline 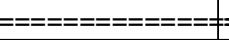 & & $==============$ & & & & $==========$ & & $=========$ & \\
\hline \multicolumn{2}{|c|}{ For Data analyzed on 9-19-00, } & $\%$ SD of Cal. Stds & sigma \% & 10.4 & 3.2 & 5.4 & 4.2 & & \\
\hline \multicolumn{2}{|c|}{ 9-27-00, 10-2-00,10-09- } & SD of Blk Std & sigma prime $\mathrm{ug} / \mathrm{ml}$ & 0.002 & 0.020 & 0.007 & 0.006 & & \\
\hline \multicolumn{10}{|l|}{ Ŝpecimen } \\
\hline \multirow[t]{2}{*}{ Ta7 } & $1100 \mathrm{C} / 4$ hours & & & & & & & & \\
\hline & Air & A & RXN tube(no ID)ug/ml & & -0.038 & 0.035 & 0.660 & & \\
\hline \multirow[t]{2}{*}{ Time, $\mathrm{h}$} & $08 / 15 / 2000$ & B & Col. tube,(Set 12) ug/ml & & -0.008 & -0.002 & 0.007 & & \\
\hline & & C & QW filter,ug/ml & & -0.021 & 0.008 & 0.030 & & \\
\hline \multirow[t]{3}{*}{4} & & $(A+B+C)$ & subtotal, ug & & -3.350 & 2.050 & 34.850 & & \\
\hline & & & $\pm \mathrm{ug}$ & & 0.141 & 0.194 & 2.775 & & \\
\hline & & $a(\mathrm{RXN})$ & Ta7 RXN FB, ug/ml & & 0.018 & 0.010 & 0.037 & & \\
\hline \multirow[t]{2}{*}{ Notes: } & & $\mathrm{b}(\mathrm{Col} \mathrm{T})$ & Ta7 CT FB, ug/ml & & 0.011 & & 0.022 & & \\
\hline & & c (QW blank) & QW mean, ug/ml & & 0.030 & 0.001 & 0.012 & & \\
\hline \multicolumn{2}{|c|}{ 1) All $50 \mathrm{ml}$ aloqoits. } & $(a+b+c)$ & subtotal, ug & & 2.950 & 0.550 & 3.550 & & \\
\hline & & & \pm ug & & 3.464 & 1.212 & 1.039 & & \\
\hline & & $(A+B+C)-(a+b+c)$ & Total, ug & & -6.300 & 1.500 & 31.300 & & \\
\hline & & & \pm ug & & 3.467 & 1.228 & 2.963 & & \\
\hline & & $\mathrm{DL}\left(3^{*} \mathrm{SD}\right)$ & $\mathrm{ug} / \mathrm{ml}$ & & 0.060 & 0.021 & 0.018 & & \\
\hline & & $\mathrm{DL}\left(3^{\star} \mathrm{SD}\right)$ & ug & & 3.000 & 1.050 & 0.900 & & \\
\hline & & \multirow{2}{*}{\multicolumn{2}{|c|}{ Total Corrected for DL }} & & & & & & \\
\hline & & & & & 3.000 & 1.500 & 31.300 & & Total \\
\hline & & & & & & & & & $\mathrm{g} / \mathrm{m} 2-\mathrm{h}$ \\
\hline & \multicolumn{2}{|c|}{ As calculated flux values: } & Mass Flux, g/m2-h & & 4.82E-04 & $2.41 \mathrm{E}-04$ & 5.03E-03 & & $5.75 \mathrm{E}-03$ \\
\hline & & & $\pm \mathrm{g} / \mathrm{m} 2-\mathrm{h}$ & & 5.57E-04 & 1.97E-04 & 4.76E-04 & & g \\
\hline & & & $\pm \%$ & & 115.57 & 81.86 & 9.47 & & $3.58 \mathrm{E}-05$ \\
\hline & \multicolumn{2}{|c|}{ Flux values with Eng.Judgement: } & Mass Flux, g/m2-h & & $4.82 \mathrm{E}-04$ & $2.41 \mathrm{E}-04$ & 5.03E-03 & & \\
\hline & \multicolumn{2}{|c|}{ Errors not applicable } & $\pm \mathrm{g} / \mathrm{m} 2-\mathrm{h}$ & & 5.57E-04 & 1.97E-04 & 4.76E-04 & & \\
\hline & & & $\pm \%$ & & 115.57 & 81.86 & 9.47 & & \\
\hline \multirow{2}{*}{\multicolumn{10}{|c|}{ Specimen: Ta7 }} \\
\hline & & & & & & & & & \\
\hline & Dimensions: & $\mathrm{t}$ avg, $\mathrm{cm}$ & $\mathrm{h}$ avg., $\mathrm{cm}$ & w avg., $\mathrm{cm}$ & & & & & \\
\hline & & 0.2696 & 2.5410 & 2.5254 & & & & & \\
\hline & Area, m2 & 0.001557 & & & & & & & \\
\hline & weight, $\mathrm{g}$ & 28.8799 & & & & & & & \\
\hline
\end{tabular}


Ta8: Tested at $1200^{\circ} \mathrm{C}$ for 2 hours in air $(1000$ sccm flow rate)

\begin{tabular}{|c|c|c|c|c|c|c|c|c|c|}
\hline & & & & Co & $\mathrm{Hf}$ & $\mathrm{Ta}$ & W & & \\
\hline Specimen Ta8 & & & & wavelenght & wavelenght & wavelenght & wavelenght & & \\
\hline (Date of Anal.) & Conditions & & Component & 228.6 & 282.0 & 263.5 & 207.9 & & \\
\hline 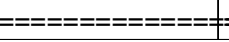 & & $==============$ & & & & $===$ & & $=========$ & \\
\hline \multicolumn{2}{|c|}{ For Data analyzed on 9-19-00, } & $\%$ SD of Cal. Stds & sigma \% & 10.4 & 3.2 & 5.4 & 4.2 & & \\
\hline \multicolumn{2}{|c|}{ 9-27-00, 10-2-00,10-09- } & SD of Blk Std & sigma prime $\mathrm{ug} / \mathrm{ml}$ & 0.002 & 0.020 & 0.007 & 0.006 & & \\
\hline \multicolumn{10}{|l|}{ Ŝpecimen } \\
\hline \multirow[t]{2}{*}{ Ta8 } & $1200 \mathrm{C} / 2$ hours & & & & & & & & \\
\hline & Air & A & RXN tube(no ID)ug/ml & & -0.026 & 0.019 & 1.186 & & \\
\hline \multirow[t]{2}{*}{ Time, $\mathrm{h}$} & $08 / 17 / 2000$ & $B$ & Col. tube,(Set 12) ug/ml & & 0.012 & -0.009 & 0.200 & & \\
\hline & & C & QW filter,ug/ml & & -0.039 & 0.028 & 5.926 & & \\
\hline \multirow[t]{3}{*}{2} & & $(A+B+C)$ & subtotal, ug & & -2.650 & 1.900 & 365.600 & & \\
\hline & & & $\pm \mathrm{ug}$ & & 0.155 & 0.189 & 25.397 & & \\
\hline & & $a(R X N)$ & Ta8 RXN FB, ug/ml & & -0.013 & 0.000 & 0.021 & & \\
\hline \multirow[t]{2}{*}{ Notes: } & & $\mathrm{b}(\mathrm{Col} \mathrm{T})$ & Ta8 CT FB, ug/ml & & -0.038 & 0.007 & 0.021 & & \\
\hline & & c (QW blank) & QW mean, ug/ml & & 0.030 & 0.001 & 0.012 & & \\
\hline \multicolumn{2}{|c|}{ 1) All $50 \mathrm{ml}$ aloqoits. } & $(a+b+c)$ & subtotal, ug & & -1.050 & 0.400 & 2.700 & & \\
\hline & & & \pm ug & & 3.464 & 1.212 & 1.039 & & \\
\hline & & $(A+B+C)-(a+b+c)$ & Total, ug & & -1.600 & 1.500 & 362.900 & & \\
\hline & & & \pm ug & & 3.468 & 1.227 & 25.418 & & \\
\hline & & $\mathrm{DL}\left(3^{*} \mathrm{SD}\right)$ & $\mathrm{ug} / \mathrm{ml}$ & & 0.060 & 0.021 & 0.018 & & \\
\hline & & $\mathrm{DL}\left(3^{*} \mathrm{SD}\right)$ & ug & & 3.000 & 1.050 & 0.900 & & \\
\hline & & \multirow{2}{*}{\multicolumn{2}{|c|}{ Total Corrected for DL }} & & & & & & \\
\hline & & & & & 3.000 & 1.500 & 362.900 & & Total \\
\hline & & & & & & & & & $\mathrm{g} / \mathrm{m} 2-\mathrm{h}$ \\
\hline & \multicolumn{2}{|c|}{ As calculated flux values: } & Mass Flux, g/m2-h & & 9.63E-04 & $4.81 \mathrm{E}-04$ & 1.16E-01 & & $1.18 \mathrm{E}-01$ \\
\hline & & & $\pm \mathrm{g} / \mathrm{m} 2-\mathrm{h}$ & & $1.11 \mathrm{E}-03$ & 3.94E-04 & 8.16E-03 & & g \\
\hline & & & $\pm \%$ & & 115.59 & 81.81 & 7.00 & & 3.67E-04 \\
\hline & \multicolumn{2}{|c|}{ Flux values with Eng.Judgement: } & Mass Flux, g/m2-h & & 9.63E-04 & $4.81 \mathrm{E}-04$ & $1.16 \mathrm{E}-01$ & & \\
\hline & \multicolumn{2}{|c|}{ Errors not applicable } & $\pm \mathrm{g} / \mathrm{m} 2-\mathrm{h}$ & & $1.11 \mathrm{E}-03$ & 3.94E-04 & 8.16E-03 & & \\
\hline & & & $\pm \%$ & & 115.59 & 81.81 & 7.00 & & \\
\hline \multirow{2}{*}{\multicolumn{10}{|c|}{ Specimen: Ta8 }} \\
\hline & & & & & & & & & \\
\hline & Dimensions: & $\mathrm{t}$ avg, $\mathrm{cm}$ & $\mathrm{h}$ avg., $\mathrm{cm}$ & w avg., $\mathrm{cm}$ & & & & & \\
\hline & & 0.2701 & 2.5450 & 2.5226 & & & & & \\
\hline & Area, m2 & 0.001558 & & & & & & & \\
\hline & weight, $\mathrm{g}$ & 28.9705 & & & & & & & \\
\hline
\end{tabular}

